\title{
Czechs Abroad
}

Once again the memory creeps in of the strange landscapes that my imagination fabricated after reading any of the Arab tales Hezar efsane [sic] - a thousand stories. And it seems to me that the memory itself assumes the form of the alluring and sharp-witted Scheherezade, who was able to entertain King Shahriyar for so many nights not only with her fairy tales but also with her charms, and that the beautiful Scheherezade not only tells me about the magic of the towns in which Alladin's lanterns shone, in which Leilas and Medjims [sic] raved of their love, in which wise Omars and powerful and cruel sultans and viziers ruled, but also shows me breath-taking marvels of nature, and leads me through silent, but endless cemeteries of stone turbans and golden lilies, and then stays standing with me before the thick grilles and mysterious life of the harems and reveals to me which way history has rolled out of the Bosphorus...

SVÁTEK K $1909^{1}$

References to The Thousand and One Nights, also called "The Arabian Nights" in English, are among the tropes and clichés that abound in 18th- and 19thcentury travel writing on the Ottoman Empire. ${ }^{2}$ Czech travelers were familiar with these tales, but hardly anybody mentioned them more than Josef Jan Svátek (1870-1948), a prolific author who wrote everything from novels and travel books to legal treatises. Svátek graduated in law in Prague and then

1 Josef Jan Svátek, Vzemi půlměsíce: Cestovní causerie (Prague: Fr. Ǩivnáč, 1909), 1.

2 See Billie Melman, Women's Orients: English Women and the Midddle East, 1718-1918; Sexuality, Religion and Work (Ann Arbor: University of Michigan Press, 1992), 63-67 and 99-123; Fatma Moussa-Mahmoud, "English Travellers and the Arabian Nights," in The Arabian Nights in English Literature: Studies in the Reception of the Thousand and One Nights into British Culture, ed. Peter L. Caracciolo (Houndmills: Macmillan Press, 1988), 95-110; Armelle Girinon, "Constantinople de Théophile Gautier et Edmondo De Amicis ou la ville ineffable," Viatica, no. 4 (2017), accessed May 3, 2020, https://hal.archives-ouvertes.fr/hal-02070365/document; Saree Makdisi and Felicity Nussbaum, "Introduction," in The Arabian Nights in Historical Context: Between East and West, ed. Saree Makdisi and Felicity Nussbaum (Oxford: Oxford University Press, 2008), 1-24; Reinhold Schiffer, Oriental Panorama: British Travellers in 19th Century Turkey (Amsterdam: Rodopi, 1999), esp. 144. 
studied at the Ecole des sciences politiques in Paris. He lived in London and Berlin and later worked as a journalist, translator, and civil servant in Prague, and he traveled extensively. ${ }^{3}$ Scheherezade appears in a book in which Svátek describes his journey to Istanbul, and she accompanies him as his Muse throughout the travelogue. But Svátek's Ottoman Empire is more than a land of exotic fairy tales. Contemplating the breathtaking views of Istanbul, he exclaims: "On the beautiful Bosphorus! One indeed forgets that one is in the country of such darkness, such degeneracy, of a lazy, almost cowardly fatalism, and of a barbaric regime, which from the very first step erect not merely the Wall of China but the seven walls of Constantinople between the European and the Turk."

Words expressing both enchantment and disgust with Istanbul, much like Svátek felt, had been written by many travelers before him. ${ }^{5}$ Although Czech travel writing on the late Ottoman Empire did not differ in this respect from travelogues published in the 19th century elsewhere in Europe, the use of the same tropes and metaphors does not necessarily mean the purpose and context of the travel writing were also the same. Travel constructs a relationship between the Self and the world ${ }^{6}$ and is instrumental in creating images of Others, not only in the eyes of the individual traveler but also on a collective level, and this process cannot be separated from the broader social and political conditions that shape the very meaning of the concepts of Self and Other. Travel writing is thus a reflection of the views that exist in the author's own society, and the images of other places and peoples are being produced with the readers at home in mind. Czechs traveled from the Czech lands, which belonged to the Habsburg Empire and from 1867 the Austro-Hungarian Empire, and one of the questions this chapter asks is how this fact affected what relationship Czech travelers adopted toward the Ottoman Empire and its inhabitants.

The most productive analysis of modern travel has been performed within the framework of (post)colonial studies, which seek to reevaluate the relations between colonial powers and their (former) colonies. ${ }^{7}$ Postcolonial studies have shed light on the way 19 th-century travel writing identified primarily with the interests of the people in European societies who aspired to influence,

3 Ottův slovník naučný (Prague: Jan Otto, 1906), 24:413.

4 Svátek, Vzemi půlměsíce, 24-25.

5 See Girinon, "Constantinople"; Schiffer, Oriental Panorama, 151.

6 Youngs, The Cambridge Introduction to Travel Writing, 9 and 12.

7 Peter Hulme and Russell McDougall, "Introduction: In the Margins of Anthropology," in Writing, Travel and Empire: In the Margins of Anthropology, ed. Peter Hulme and Russell McDougall (London: I.B. Tauris, 2007), 5-7. 
exploit, or directly control the non-European world. ${ }^{8}$ Views on the travelers' complicity in the imperial project differ: while some scholars are critical of any work that romanticizes or rationalizes the Middle East, ${ }^{9}$ others try to differentiate between discourse that is more overtly imperialist and Orientalist and that which is more neutral in this respect. ${ }^{10}$ In either case, postcolonial theory invariably associates travel in the 19th and early 20 th centuries with the existence and aims of empires; there is even "a sense in which all travel writing, as a process of inscription and appropriation, spins webs of colonizing power..."11

Because the 19th century was so much in the grip of imperial projects and the imperial mentality, it is often assumed that all travel was either "colonial" or "reverse" travel 12 from the (former) colonies to the metropoles. Even when the colonial framework was absent, there was what Vesna Goldsworthy calls "narrative colonization" or "textual colonization." Analyzing Western exploitation of the literary construction of the Balkans, she argues that "[t]he process of literary colonization, in its stages and its consequences, is not unlike real colonization. It begins with travel writers, explorers and adventurers undertaking reconnaissance missions into an unknown area." ${ }^{13}$ Although Western countries had no colonies in the Balkans, the Western producers of colonial discourse examined by Goldsworthy nonetheless actually were citizens of colonial powers. Travels that lie outside the colonizer/colonized dichotomy are often neglected in theoretical analyses within postcolonial studies. Travel literature, including examples of "non-colonial" travel, has been dealt with in studies in the area of imagology:14 some of these studies explore (post-)Enlightenment and Romantic travel writings, which increasingly began to talk in

8 Roy Bridges, "Exploration and Travel outside Europe," in The Cambridge Companion to Travel Writing, ed. Peter Hulme and Tim Youngs (Cambridge: Cambridge University Press, 2002), 53 .

$9 \quad$ Ussama Makdisi, "Mapping the Orient: Non-Western Modernization, Imperialism, and the End of Romanticism," in Nineteenth-Century Geographies: The Transformation of Space from the Victorian Age to the American Century, ed. Helena Michie and Ronald R. Thomas (Rutgers: Rutgers University Press, 2003), 40-54.

10 Geoffrey Nash, "Politics, Aesthetics and Quest in British Travel Writing on the Middle East," in Travel Writing in the Nineteenth Century: Filling the Blank Spaces, ed. Tim Youngs (London: Anthem Press, 2006), 55-69.

11 James Duncan and Derek Gregory, "Introduction," in Writes of Passage: Reading Travel Writing, ed. James Duncan and Derek Gregory (London: Routledge, 1999), 3.

12 Youngs, The Cambridge Introduction to Travel Writing, 10-11 and 115-30.

13 Vesna Goldsworthy, Inventing Ruritania: The Imperialism of the Imagination (New Haven, CT: Yale University Press, 1998), 2-3.

14 Albert Meier, "Travel Writing," in Beller and Leerssen, Imagology, 446-50. See also DanielHenri Pageaux, Images du Portugal dans les lettres français (1700-1755) (Paris: Fondation Gulbenkian, 1971). 
terms of the Self and the Other, and which became an important source of national stereotypes. ${ }^{15}$

In their pioneering work on East European travel writing, Wendy Bracewell and Alex Drace-Francis note the absence of any discussion of East European travel from general analyses of both literature and travel writing. ${ }^{16}$ In the introduction to the book, the editors point to various shared features of the travel writing on Europe that emerged from Central and East European countries. East European travelers reacted in their writing to their home societies' contested place in Europe; they were confronted with the realization that "Europe is elsewhere," and they sought to address this in their work and engage with others' assumptions about their alleged lack of Europeanness. For East European travelers, Europe could thus mean an encounter with both Self and Other and their travel writing served as a means by which they tried to integrate their homeland into this Europe. ${ }^{17}$ Izabela Kalinowska has similarly argued that for some Polish and Russian writers, "travel to the East provided a way to assert their own westernness and hence Europeanness."18

The centrality of the concept of Europe in travel literature was not limited to Eastern Europe. Gayle Nunley has shown the importance of "the idea of Europe" for 19th-century Spanish travelers to both European and non-European destinations: Spanish travelers "took on an essential European traveler identity," but this identification was complicated by the common conceptualization of Europe in the terms of a North-South divide, in which Spain was perceived as part of the traditional, less modern South. ${ }^{19}$ Spanish writers, including those who described journeys to the Eastern Mediterranean, thus found it difficult to locate their culture in the East-West paradigm that was typical of European writing on travel to the "Orient." ${ }^{20}$ Europeanization and modernization were common topics in their travel chronicles, and they were usually discussed when authors were trying to persuade their readers of the virtues of these projects. The Spanish case differed from the "classical" model of the colonial empire:

15 Alida Johanna Louise Coenen, The Image of Spain in Dutch Travel Writing (1860-1960) ('sHertogenbosch: Uitgeverij вох Press, 2013), 6-12. See also Elke Mehnert, ed., Imagologica Slavica: Bilder vom eigenen und dem anderen Land (Frankfurt am Main: Peter Lang, 1997).

16 Alex Drace-Francis, "Towards a Natural History of East European Travel Writing," in Bracewell and Drace-Francis, Under Eastern Eyes, 1. See also Wendy Bracewell and Alex Drace-Francis, "Foreword," in Bracewell and Drace-Francis, Under Eastern Eyes, viI.

17 Bracewell and Drace-Francis, "Foreword," IX.

18 Izabela Kalinowska, Between East and West: Polish and Russian Nineteenth-Century Travel to the Orient (Rochester: University of Rochester Press, 2004), 3.

19 Gayle R. Nunley, Scripted Geographies: Travel Writings by Nineteenth-Century Spanish Authors (Lewisburg, PA: Bucknell University Press, 2007), 123-34.

20 Nunley, Scripted Geographies, 20. 
Spanish travelers were painfully aware of the diminishing status of Spain as a colonial power, and, as Nunley points out, the Spanish version of Orientalism was primarily, though not exclusively, directed at Spain's own "Orient," i.e. the South of Spain. ${ }^{21}$

A sense of the Orient's proximity was felt in Southeastern Europe, too, but it had different connotations. Bracewell notes that in Southeastern Europe Ottoman-Turkish subjects served as a negative mirror: when travelers praised the Ottoman Empire it was in order to criticize problems in their home societies. Although East European authors followed (West) European literary models and cultural patterns, they did not portray Ottoman reality as exotic because it was very familiar to them..$^{22}$ The Czechs, who never experienced direct Ottoman rule, did not feel the same "ethnic closeness and familiarity with Ottoman ways of life," which in some East European societies "put an added emphasis on religion as the crucial factor that differentiated these travelers' societies from that of the Turk." ${ }^{23}$ Czechs represented the West in the eyes of Eastern Slavs, ${ }^{24}$ but as Slavs themselves they were still seen as "Eastern" by many West Europeans, and among the other things they shared with East European travelers was the importance of "Europe" for their identity. The question then is whether Czech travel writing on the Ottoman Empire was indeed trying to establish or confirm a place for Czech society in Europe, which, according to Bracewell, was a common objective of travel literature from Eastern Europe. ${ }^{25}$

Czech travel and travel literature have been explored from various points of view and through various disciplinary approaches, but mainly within the framework of national history and without attempts at broader comparisons. Many studies of Czech travel and exploration writing have described the travelers' hardships and emphasized their passion for discovery and the results of their explorations. ${ }^{26}$ Literary scholars and historians have looked at travel accounts as an important form of early modern and modern Czech literature and

21 Nunley, Scripted Geographies, 17 and 127-30. Nunley (131) writes though that most Spanish works describing travels to the Orient at the time were produced in the service of the Spanish colonialist enterprise and were aligned with the pursuit of empire.

22 Bracewell, "The Limits of Europe," 78.

23 Ibid., 80.

24 Ibid., 120.

25 Ibid., esp. 81.

26 Kunský, Čeští cestovatelé; Simona Binková and Josef Polišenský, Česká touha cestovatelská: Cestopisy, deníky a listy ze 17. století (Prague: Odeon, 1989); Miloslav Martínek and Jiří Martínek, Čeští cestovatelé a mořeplavci (Prague: Albatros, 2006). For a different perspective see Vladimír Rozhoň, Čeští cestovatelé a obraz zámoř́ v české společnosti (Prague: Aleš Skřivan ml., 2005); Jůnová Macková et al., "Krásný, báječný, neštastný Egypt!" 
as historical sources, ${ }^{27}$ while studies on the formation of Czech national society have focused on the 19th-century travelers who were part of the Czech "national revival." ${ }^{28}$ Attempts to analyze Czech travel to non-European countries as reflections of power relations, hierarchies, and Orientalist attitudes are, however, rare. ${ }^{29}$ One of the exceptions is Sarah Lemmen's recent book on the role that travels outside Europe had in the construction of Czech national identity. Dealing with travels to the entire non-European world from 1890 to 1938, Lemmen situates Czech nationalism in the framework of globalization and shows the importance of Czechs' attitudes to the colonial system. ${ }^{30}$

The Czech relationship with the Ottoman Empire can hardly be described in colonial terms. ${ }^{31}$ In the late 19th century, the emerging Czech industrial and financial sectors had limited interests in the Ottoman Empire. However, up until 1918, Czechs traveled as citizens of the Habsburg Empire and some of them explicitly embraced its imperial outlook. Czechs who traveled to areas outside Europe (or to Europe's Southeastern peripheries) enjoyed privileged status in relation to most of the local population. While critical of the Habsburgs' expansionist plans and with no colonies of their own, Czechs nevertheless figure among the European travelers whose travel writing, in the words of Mary Louise Pratt, produced "the rest of the world" for European, in this case Czech, readers and Europe's various conceptions of itself in relation to this putative "rest of the world."32

This chapter examines how Czechs who visited the late Ottoman Empire viewed the Turks and their country and shows what interested them during their trip. Although their travelogues contained intriguing information, some of which is new for us, too, in most cases their authors did not stay in the Ottoman territories long enough to gain insight into important issues in the turn-of-thecentury Ottoman Empire; the information is therefore mainly anecdotal and

27 Michael Borovička, Velké dějiny zemí Koruny české: Tematická řada Cestovatelství (Prague: Paseka, 2010).

28 Jana Šormová, Náprstkův dům a čeští cestovatelé (Prague, 1953).

29 See, e.g., Hana Navrátilová and Lucie Storchová's essays in Storchová, "Mezi houfy lotrův se pustiti..."; Vladimír Rozhoň, "Zámoří v povědomí české společnosti," in Piorecká and Petrbok, Cizí, jiné, exotické, 38-53; Adéla Macková and Hana Navrátilová, "Egypt a čeští cestovatelé na přelomu 19. a 20. století," in Piorecká and Petrbok, Cizí, jiné, exotické, $67-78$.

3o Lemmen, Tschechen auf Reisen.

31 The case of Bosnia and Herzegovina will be dealt with in the following chapter ("Civilizing the Slavic Muslims of Bosnia-Herzegovina"). For the Czechs' relationship to other non-European teritorries at the turn of the century and in interwar Czechoslovakia see Lemmen, Tschechen auf Reisen.

Pratt, Imperial Eyes, 5 . 
focuses on people and things that were expected to amuse Czech readers. This certainly did not prevent the travelers from expressing firm views on the country and its inhabitants, and we will see in this chapter whether the images presented from their first-hand experience diverged from the images promulgated in the brochures on the Turks published at that time and analyzed in the previous chapter. This chapter asks how Czech travel writing on the Ottoman Empire reflected the position of dominance that is typically identified in European travelogues on the non-European world, and whether and how it was an expression of the imperial context. Without a colonial empire and even a state of their own, on what did the Czechs base their sense of superiority over the inhabitants of the Ottoman Empire? Did they travel and write as West Europeans, as representatives of the Habsburg Empire, or as East/Central Europeans?

This analysis focuses on travel accounts published between the late $186 \mathrm{os}^{33}$ and the establishment of Turkey in 1923. It examines descriptions of journeys that were made at different times and to different destinations, though most travelers also visited the Ottoman capital, and the purposes of the travel and the reason each author had for writing about it varied, as did the form of the work and its literary quality. The chapter does not attempt to offer a systematic survey of travels or a typology of travel narratives, ${ }^{34}$ nor does it analyze travel accounts as literary texts; whatever differences in form and content, they are all treated as sources on their authors' attitudes to the Ottoman Empire and its inhabitants. For the purpose of this analysis travel writing is thus broadly defined as "predominantly factual, first-person prose accounts of travels that have been undertaken by the author-narrator." 35

The chapter first introduces the context of Czech travels and the travelers' preparations for their journeys, including their knowledge of available literature on the Ottoman Empire, and then it shows the first impressions that travelers came away with from an Ottoman Empire constructed as an Oriental space. It examines where Czech travelers located the Ottoman Empire on the mental map of human development, divided as it was at the turn of the century between the "pre-modern," or "backward," and the "modern" world. The second

33 A few examples of travel narratives from the late 186os are included because they were written by famous writers and were widely read and cited.

34 For an overview of Czech travels see Kunský, Čeští cestovatelé; Borovička, Cestovatelství.

35 Youngs, The Cambridge Introduction to Travel Writing, 3. David Chirico proposed a "provisional definition" of travel narratives in the volume on East European travels: "A nonfictional first-person prose narrative describing a person's travel(s) and the spaces passed through or visited, which is ordered in accordance with, and whose plot is determined by, the order of the narrator's act of travelling." David Chirico, "The Travel Narrative as a (Literary) Genre," in Bracewell and Drace-Francis, Under Eastern Eyes, 39. 
part of the chapter focuses on Czech perceptions of the Ottoman population: Turkish men and women and people from other ethnic groups.

\section{$1 \quad$ Getting Ready to Travel}

Although traveling became a popular middle-class activity in the Czech lands later than it did in Western Europe, by the early 2oth century the number of Czech travelers to and travel accounts about the Ottoman Empire was on the rise. ${ }^{36}$ Many travelers, especially the ones who published accounts of their journeys, were intellectual elites: writers and journalists, teachers and scholars, lawyers and medical doctors. The social spectrum of travelers gradually broadened, but with a few exceptions the authors of travel books were all men. Czech women did travel, and some even wrote accounts of their experiences, but they did not publish travelogues about the Ottoman Empire in the time before its dissolution. ${ }^{37}$ Apart from the women who visited the non-Ottoman Balkans, ${ }^{38}$ some Czech women worth noting who traveled in the former Ottoman realm include Vlasta Kálalová (di Lotti), who worked as a physician in Baghdad in the 1920 and early 1930s and whose short travelogue published in 1933 described also her stay in Istanbul, ${ }^{39}$ and Ludmila Matějková (Matiegková), an Egyptologist and the author of a travel book on Egypt that was published in

$36 \quad$ The authors of the travelogues included writers, journalists, and scholars, many of whom were famous personalities. The potential impact of their works on readers, however, is left aside here. In general terms, the readership of Czech non-fiction works was becoming wider in the second half of the 19th century; as well as higher and middle classes, members of the lower-middle classes and women also started to appear among readers of popular non-fiction works. See Milena Lenderová, "Čtenáři a četba," in $Z$ dějin české každodennosti:Životv 19. století, ed. Milena Lenderová, Tomáš Jiránek, and Marie Macková (Prague: Karolinum, 2009), 328-46. One travelogue to Monte Negro (Holeček, Černá Hora) was published by a society whose aim was to spread non-trivial works among the poor (Spolek pro vydávání laciných knih českých, zaměrený na šírení kvalitněǰś literatury mezi nemajetnými vrstvami).

37 Most women who published travel books in the first decades of the 2oth century were writers; their travel accounts often described journeys to Central Europe (Božena VikováKunětická, Anna Řeháková) and to Southern Europe (Anna Řeháková), but also to Scotland (Julie Procházková) and America (Marie Zieglerová). Barbora Markéta Eliášová, who traveled to Japan and made a journey around the world, stands out among the first generation of Czech women traveling outside Europe. See Barbora Markéta Eliášová, Rok života mezi Japonci a kolem zeměkoule (Prague: printed by author, 1915).

38 Some of these women will be mentioned in the following chapter.

39 Vlasta Kálalová-di Lottiová, Cařihradské a bagdádské kapitoly (Prague: printed by author, 1933). 
$1927 .^{40}$ In general, however, the Czechs resembled other East Europeans, among whom, as Bracewell and Drace-Francis remark, "this genre does not seem to have been as attractive as it was to women in the Anglophone world, for instance." ${ }^{41}$

Before embarking on a trip, as well as planning the route and choosing the means of transportation, travelers had to get a travel document. For citizens of many European states in the 19th century, passports were becoming less important for traveling within Europe, ${ }^{42}$ but until 1867 inhabitants of the Habsburg Empire had to have a passport for domestic as well as international travel. In the late 19th century, there were no passport controls at the borders of the Austro-Hungarian Empire anymore, and passports were only needed to visit countries that required travelers to have them; the Ottoman authorities not only requested passports but also expected travelers to have a visa. ${ }^{43}$ Rail and ship were the most common means of transportation throughout the period and each of these modes had its fans. Both means of transport sometimes also played a role in the travelogues, as the authors used the description of their journey by rail or ship as an opportunity to establish their position as an observer - and in some cases to tell a story of the suffering they had endured. ${ }^{44}$ Most Czechs visited Istanbul and some parts of what either used to be or still were the Ottoman Balkans, and a few traveled to more remote parts of the empire - for example, expeditions to explore Asia or Africa passed through Ottoman territory. Some travelers went to the Ottoman lands on an official mission, while others pursued semi-scholarly aims, but the majority traveled for leisure. ${ }^{45}$

40 Ludmila Matiegková, Vobjetí sfingy (Prague, 1927).

41 Bracewell and Drace-Francis, "Foreword," XI.

42 Andreas Fahrmeir, "Governments and Forgers: Passports in Nineteenth-Century Europe," in Documenting Individual Identity: The Development of State Practices in the Modern World, ed. Jane Caplan and John Torpey (Princeton, NJ: Princeton University Press, 2001), 233 .

43 Jan Rychlík, "Pasové předpisy v habsburské monarchii a v Československu," in Cestování Čechů a Poláků v 19. a 20. století, ed. Petr Kaleta and Lukáš Novosad (Prague: Masarykův ústav, 2008), 9-11.

44 Svátek traveled by boat (Svátek, Vzemi půlměsíce, 3), and Klaus compared the advantages of traveling by boat and train. Alois Klaus, Do ř́š́e půlměsíce (Prague: Nakladatelství E. Beaufort, n.d., ca. 1910), 5 .

45 Klement (Quido Mansvet) writes as a tourist giving advice to other tourists (František Klement, "O Turkyních," Národní listy, November 29, 1895), 1; Wagner implies he is a tourist. Jan Wagner, Na evropském východě: Črty z cest po Bulharsku, Turecku, Řecku, Německu a Rusi (Třebíč: Nakl. J.F. Kubeš, n.d., ca. 1889), 186. Klaus repeatedly identifies as a tourist (Klaus, Do ř́šse půlměsíce, 5). Some of the travelers also visited Egypt, but given the separate tradition of Egyptian travels, the descriptions of that part of their journeys are for the 
Regardless of their destination, Czech travelers in the Ottoman Empire did not "discover" any new places on the map. Some scholars make a distinction between travelers, explorers, and tourists. Sachidananda Mohanty notes that while explorers seek places not yet discovered, travelers visit places that they learn about from their own research and that are known from history, and tourists go to places targeted by travel businesses and ready for group tours; the explorer is attracted by the risk of the unknown, the tourist prefers the safety of the known, and the traveler is somewhere in between these two poles. ${ }^{46}$ Only a few travel writers mentioned in this chapter were explorers, traversing the Ottoman Empire on their way to less familiar regions or at the start of a journey around the world. ${ }^{47}$ Most trips made by Czechs to the Ottoman Empire were touristic, but none of them took the form of organized tourism. While in Britain tourism had become so common by the late 19th century that it almost acquired negative connotations, ${ }^{48}$ for Czechs tourism still bore the whiff of something new and exciting. One Czech traveler, a teacher named Alois Klaus, proudly identified himself as "a modest Czech tourist" who wrote a travel book in order to show that it was possible even with little money, using contacts with Czechs abroad, to make interesting touristic journeys to the Orient. ${ }^{49}$

Modern Czech travelers to the Ottoman Empire started their journeys equipped with some knowledge of the vast literature on the region, much like travelers from any other country, ${ }^{50}$ and their travel impressions were influenced by the preconceived notions and ideas they had about the places and peoples they were going to visit and by what others had written about them. References to guidebooks on the Middle East were rare before World War I; 51 Czech travelers instead cited famous foreign and Czech authors who had described their trips to the Ottoman Empire. Some of them even copied parts

most part not included here. See Jůnová Macková et al., "Krásný, báječný, neštastný Egypt!," esp. 9.

46 Mohanty, "Introduction," xi. One of the travelers to the Ottoman Empire, Jiří Guth, also reflected on the difference between a traveler and tourist. See Macková and Navrátilová, "Egypt a čeští cestovatelé," 72 (note 13).

47 Josef Kořenský, Asie: Kulturní obrázky z asijského jihu a západu; Malajsko, Cejlon, Indie, Persie, Palestina, Arabie, Mesopotamie, Armenie, Malá Asie (Prague: A. Storch syn, n.d., ca. 1921).

48 Youngs, The Cambridge Introduction to Travel Writing, 59.

49 Klaus, Do řiše pưlměsice, [279].

5o Duncan and Gregory, "Introduction," 7; Tim Youngs, "Introduction," in Youngs, Travel Writing in the Nineteenth Century, 6.

51 Perhaps the number of Czech travelers to the Middle East was not sufficient to make publishing guides in Czech worth the cost. Czech travelers to Istanbul therefore often depended on German Baedekers. 
of earlier travelogues into their own, often without acknowledging the original author. In keeping with the notion widespread among 19th-century Europeans of "the Orient" and its inhabitants as changeless, an important source of information for Czech travelers were Czech travelogues written between the 15th and early 17 th centuries that described visits to the Holy Land and diplomatic missions to the Ottoman Sultan. These works, which were published for the first time or reissued in the 19th century in response to the new national interest in the Czech language and literature, became part of the national literary canon and were well known among the educated public. Lucie Storchová, who writes about Egypt, considers the travelogue by Kryštof Harant, a Renaissance nobleman, to be a text of great significance that influenced "the specific form of Orientalism" that the modern Czech nation came to espouse. As Storchová sees it, modern Czech Orientalism was essentially based on a revised version of the premodern Orientalism that Harant had introduced. ${ }^{52}$

The Czechs who traveled in the 19th century to the Ottoman capital, however, referred more often to the travel account of Václav Vratislav z Mitrovic, who as a young man in the 1590 os accompanied Rudolph II's mission to the Sultan. Although less learned than Harant, Mitrovic wrote a highly readable and very popular account of his journey. He complained about the way he was treated by the Turks, who imprisoned him, and told stories that reflected the stereotypes of his day, and he portrayed the Turks as violent and cruel. But in his description of the life and habits of the Ottoman Empire's inhabitants he proved to be an unbiased and keen observer. He often praised what he considered to be the Turks' virtues - their humility and religious fervor, their love of animals and flowers and their innocent forms of entertainment - and showed that they could be humane and tolerant. He wrote, for example, that the muchfeared janissaries, who were considered generally to be "atrocious beasts," also protected the local population, and did not indulge in lustful behavior. ${ }^{53}$ Late 19th-century and early 2oth-century travelers to the Ottoman Empire often referred to Mitrovic's work when describing some phenomenon that he had mentioned, while other travel accounts, such as Harant's travel book or Martin Kabátník's account of his late 15th-century journey to Jerusalem and Egypt, were quoted less. ${ }^{54}$

$5^{2} \quad$ Storchová, "Mezi houfy lotrův se pustiti...," 444.

53 See Adventures of Baron Wenceslas Wratislaw of Mitrowitz: What He Saw in the Turkish Metropolis, Constantinople, Experienced in His Captivity, and after His Happy Return to His Country, Committed to Writing in the Year of Our Lord 1599 (London: Bell and Daldy, 1862), 4-6.

54 Jan Neruda mentioned Harant when describing Egypt.Jan Neruda, Obrazyz ciziny (Prague: F. Topič, 1909), 191. Prášek quoted Kabátník when he wrote about Istanbul. See Justin V. 
Turn-of-the-century Czech travelers were perhaps influenced most by the travel narratives of two 19th-century Czech writers, Vítězslav Hálek (1835-1874) and Jan Neruda (1834-1891), who had visited the Ottoman Empire in 1865 and 1870 , respectively. Both were prominent Czech literary figures in their time and their travel notes, which appeared first as columns (feuilletons) in newspapers, were widely read and cited. When one traveler named Josef Štolba visited a place that Neruda had described with admiration, he declared that "whatever Neruda has put his poetry to, I daren't apply my own pen," ${ }^{55}$ but most travelers were not shy about using poetic descriptions penned by their famous predecessors. Even when they did not mention Neruda or Hálek explicitly, travelers still used their metaphors and words, visited the same places, and paid attention to the same subjects as the two famous writers. ${ }^{56}$ Toward the end of the century, travelers began to prepare for their trip by searching for more detailed information about the places that were to be visited and by studying travel guides $^{57}$ and, later, scholarly treatises written by experts, such as Alois Musil's works on Arabia. ${ }^{58}$

Czech travelers were also familiar with European travel literature on the Ottoman Empire, ${ }^{59}$ though they tended to mention just a few famous writers more frequently, most notably Lord Byron. ${ }^{60}$ Only several of Byron's works

Prášek, Dunajem do Cařihradu: Črty a vzpomínky z roků 1885 a 1886 (Prague: Alois Wiesner, 1901), 89. Kaminský among others referred to Mitrovic. See Bohdan Kaminský, Návštěvou u chorého muže: Causerie z cesty (Prague:Jos. R. Vilímek, n.d., ca. 1909), 45 and 81.

55 Josef Štolba, Ze slunných koutů Evropy: Vzpomínky z menších cest (Prague: Unie, 1918), 129.

56 This mainly involved references to the Bosphorus and the view of Istanbul, Hálek's contrast between the appearance of the city and its internal character, and also the bridge and cemetery as symbols of certain Turkish or "Oriental" qualities.

57 Klement (“O Turkyních," 1) mentioned reading the Baedeker and other guides.

$5^{8}$ Kořenský, Asie, 153; Vladislav Forejt-Alan, Za karavanou mrtvých (Prague: Nakladatelství Pražské akciové tiskárny, 1938), 14. Schwarzenberg noted that many people in the Arab regions of the Ottoman Empire knew and respected Alois Musil. See Adolf Schwarzenberg, Pod praporem tureckého půlměsíce: Válečné vzpomínky na Syrii a Palestinu (Prague: Rudolf Březina, 1926), 92.

59 Hálek, in accordance with his own views, chose to mention Dumas, who, according to him, was critical of Istanbul. Vítězslav Hálek, Cestopisy: Články z let 1861-1874 (Prague: Nakl. Borový, 1925), 155 .

6o Byron himself wrote: "Of Constantinople you have of course read fifty descriptions by sundry travellers, which are in general so correct that I have nothing to add on the subject." George Gordon Byron, The Complete Works of Lord Byron: Including the Suppressed Poems, and Others Never Before Published (Ann Arbor: University of Michigan Library, 2009), 4:XXXIII. In 1870, the literary scholar, philosopher, and translator Josef Durdík published a 200-page book on Byron's works with his own translated excerpts from Byron's texts. See Josef Durdík, O poesii a povaze lorda Byrona (Prague: J.S. Skrejšovský, 1870). 
were available in Czech translation at the end of the 19th century, but educated Czech readers would have understood the German translations or the English original. ${ }^{61}$ Childe Harold's Pilgrimage was translated into Czech by the writer Eliška Krásnohorská (whose poems on Southern Slavs and Turkish oppression were mentioned in the previous chapter) and published in 1890 and again in $1918 .{ }^{62}$ David Katz recently showed that the allegedly anti-Turkish Byron in fact tended to have positive views of the Turks: in the notes to Childe Harold's Pilgrimage, he praised their financial honesty, their generosity, and the safety of their country, and he depicted them as brave, faithful, and devout. ${ }^{63}$ In the introduction to her translation, Krásnohorská noted Byron's impact on Slavic literature (Pushkin, Lermontov, Słowacki, Krasiński, Mickiewicz, as well as on the Czech authors Mácha and Hálek), his fight for freedom and against injustice, and his support for oppressed nations, especially the Greeks. ${ }^{64}$ Most travelers, however, quoted Byron's enchanting words about the view of Constantinople. ${ }^{65}$

Among writings by other famous visitors to the Ottoman Empire, Lady Montagu's Letters did not appear in Czech translation until $1909,{ }^{66}$ and Edmondo De Amicis' Constantinopoli, despite the popularity of the author's other works among the Czech public, was not translated into Czech at all, but Czechs would have been able to read it in German or Croatian. ${ }^{67}$ As well as travel literature, French exotic novels and the works of Pierre Loti in particular were taken as true depictions of the Orient. One traveler, Jiří Guth, a proponent of the Olympic idea who is remembered today for his famous handbook on etiquette, translated Loti's Les Désanchantées (The Disenchanted) into Czech under the title "Harems Deprived of Magic," and travelers cited Loti's other

61 See, e.g., George Gordon Byron, Nevěsta z Abydu: Pověst turecká, trans. Josef Václav Frič (Prague: Tisk a náklad Jaroslava Pospíšila, 1854) and George Gordon Byron, Vězeň Chillonský, trans. Antonín Klášterský (Prague: Alois Wiesner, n.d., ca. 1900). Don Juan was not translated to Czech until the early 2oth century. See George Gordon Byron, Don Juan lorda Byrona: Satirický román ve veršich, trans. Václav Alois Jung, 2 vols. (Prague: J. Otto, 1904-5). However, it was set to music by Zdeněk Fibich already in 1882, with the libretto by Anežka Schulzová. Anežka Schulzová, Hedy: Zpěvohra o 4 jednáních (Prague: Fr. A. Urbánek, 1896).

62 George Gordon Byron, Childe-Haroldova pout', trans. Eliška Krásnohorská, 2nd ed. (Prague: Otto, 1918, first published 1890 by F. Šimáček).

63 David Katz, The Shaping of Turkey in the British Imagination, 1776-1923 (Milton Keynes: Palgrave Macmillan, 2016), 99.

64 Byron, Childe-Haroldova pout', 8-11 and 14; Katz, The Shaping of Turkey, 93.

65 See, e.g., Štolba, Ze slunných koutů Evropy, 10; Svátek, Vzemi půlměsíce, 20.

66 Mary Wortley Montagueová, Dojmy evropské a turecké, trans. Adolf Gottwald (Prague: J. Otto, n.d., ca. 1909).

67 Edmondo De Amicis, Carigrad, trans. Adolfo Veber (Zagreb: Dion. tiskara, 1883); Edmondo De Amicis, Konstantinopol, trans. Agnes Burchard, 2nd ed. (Rostock: W. Werther, 1884). 
novels as well. ${ }^{68}$ Sometimes travelers tried in their writing to evoke exotic images by making explicit or implicit references to non-Western literary works, in most cases The Thousand and One Nights or other Oriental stories (Leyla and Mejnun), as we saw in Svátek's travel narrative. ${ }^{69}$ Travelers to Istanbul thus set out to encounter the Orient with a clear expectation as to what its "orientalness" was.

Travelers to the Ottoman Empire had to cross borders that were often as much conceptual as they were geographical. They sometimes did not find crossing a state border to be important enough to be worth describing. Traveling through the Balkans in the early 2oth century, for instance, Josef Zdeněk Raušar noted rather matter-of-factly how he transferred from a Bulgarian to a Turkish train and then crossed the border into Turkey, but then he went on to describe in great detail the process of going through customs at Mustafa Pasha. ${ }^{70}$ Most travelers associated borders primarily with customs, which gave them an occasion to complain about the inefficiency of Turkish officers and their universal expectation of receiving baksheesh. The poet and translator Bohdan Kaminský referred back to what Mitrovic wrote in the late 16th century about the Ottoman habit of bribery: "And, in truth, whoever wishes to dwell amongst the Turks cannot help himself, but, as soon as he enters into their territories, must immediately open his purse, and not shut it till he leaves them again, and must constantly be sowing money as a kind of seed, since for money he can procure himself favour, love, and everything that he wants." ${ }^{.11}$ Unsurprisingly, Kaminsky's own experience on the trip he made in the early zoth century then confirmed Mitrovic's words. ${ }^{72}$ Svátek complained that when he arrived in Istanbul, the police checked the boat for ill or suspicious people, something he found

68 Svátek, Vzemi půlměsíce, 106-9, 1, and 20; Hálek, Cestopisy, 223; Štolba, Ze slunných koutů Evropy, 14.

69 Hálek also wrote poems with Oriental themes (Krásná Lejla and Mejrima a Husejn), even before he traveled to the Ottoman Empire. See Vítězslav Hálek, Sebrané spisy (Prague: Nákladem Jana Laichtera, 1905), 2:249-59 and 261-337; see also Kaminský, Návštěvou u chorého muže, 45; Růžena Svobodová, Barvy Jugoslavie: Obrázky z cest 1911 (Prague: Unie, n.d.), 82.

$70 \quad$ Jos. Zd. Raušar, Na půdě sopečné: Z potulek po Srbsku, Makedonii a Turecku (Prague: Dr. Eduard Grégr a syn, 1903), 122.

71 Mitrowitz, Adventures, 43.

72 Kaminský, Návštěvou u chorého muže, 45. 
absurd given the amount of dirt and the number of disreputable characters he claimed visitors encountered in the Ottoman Empire itself, but at least, he added, this provided foreigners with a convenient introduction to the rotten empire, whose only way of communicating with foreigners was through baksheesh. ${ }^{73}$ Detailed instructions on how to pass baksheesh (the Czech translation of the word is never used) to a customs officer so that no one else notices and so that a semblance of order is preserved appear in many travel accounts, although the tone the authors take ranges from amused to annoyed. ${ }^{74}$ One traveler complained that, since he did not respond to an obvious hint at a request for a bribe, he was forced to endlessly make the rounds of different Ottoman authorities in Skadar - who, it turned out, were not able to read Latin script - before he was finally able to get his residence permit. ${ }^{75}$

Despite the many anecdotes about first encounters with the Ottoman officials, travelers clearly considered equally important as state borders the conceptual border between Europe - the West, or in one case the North ${ }^{76}$ - and the Orient. "Entering the Orient" was a moment many travelers deemed worth commenting upon. And the moment of "entering" the Orient could occur on arrival in Istanbul, or even while the traveler was still in the Balkans: Hálek claimed to have entered the Orient in Albania, Klaus and Raušar in Serbia. ${ }^{77}$ The Orient had various connotations, much like the ones readers could find in travelogues written by other Europeans. Travelers captured the Orient by dwelling on its bazars, harems, and palaces, and its smelly narrow streets and shabby wooden houses. ${ }^{78}$ They portrayed it through its contrasts: it was the cradle of civilization and the home of the terrible hordes threatening Europe, ${ }^{79}$ its harems resembled barred prisons but equally sparked fantasies about the delights and passions hidden behind the lattice, ${ }^{80}$ the strength of the Oriental faith was contrasted with its fanaticism, the readiness of the local people for

73 Svátek, Vzemi půlměsíce, 5 .

74 Jiří Guth, Letem přes řecký kraj: Feuilletony z cest (Prague: Dr. Frant. Bačkovský, 1896), 132; Štolba, Ze slunných koutů Evropy, 16; Jiř́k mentions that, when he arrived in Alexandria, he gave the customs officer his first baksheesh, which saved his clothes from being tossed all over the place. V. Jiř́ík, K pyramidám: Zápisky z cest (Prague: Nakladatel Fr. Švejda, 1913), 33-34.

75 Viktor Dvorský and Jiří Čermák, Albánské a černohorské obrázky: Cestopisné črty z bývalých tureckých hranic (Prague: Nakladatelské družstvo Máje, n.d., ca. 1913), 28-30.

76 Wagner, Na evropském východě, 186.

77 Hálek, Cestopisy, 140; Klaus, Do ř̌šse půlměsíce, 58; Raušar, Na půdě sopečné, 11.

78 Kaminský, Návštěvou u chorého muže, 51; Svátek, Vzemi pưlměsíce, 6-7, 126, and 185-86; Wagner, Na evropském východě, 154.

79 Svátek, Vzemi pưlměsíce, 3.

8o Kaminský, Návštěvou u chorého muže, $5^{1}$ and 91. See also Raušar, Na pưdě sopečné, 130. 
sacrifices with their greed and stubbornness. ${ }^{81}$ In this vein, a beautiful evening outside accompanied by the romantic sound of the cicadas would almost necessarily be spoiled by the danger of being robbed, forcing the tourist to spend the evening at home with the bedbugs. ${ }^{82}$

In a recurring metaphor, the Ottoman Orient was likened to a bridge and was symbolized in particular by the Galata Bridge as the bustling meeting place of countless ethnicities. It was as though, in Svátek's words, the bridge contained within just a few square meters all sorts of languages and colors, people young and old, men and women of different classes - from rich to poor, pachas as well as beggars, with fezes, turbans, cylinders, and the colorful costumes of the Balkans and Asia. ${ }^{83}$ The bridge metaphor was not invented or used only by the Czechs. Edmondo de Amicis wrote in his Constantinopoli in 1878 that standing on the bridge between Galata and the opposite shore of the Golden Horn, one can see all of Constantinople go by in an hour. "Try to imagine the most extravagant contrasts of costume, every variety of type and social class, and your wildest dreams will fall short of the reality; in the course of ten minutes and in the space of a few feet you will have seen a mixture of race and dress you never conceived of before." ${ }^{\prime 4}$ Baskar describes how the Slovenian poet Aškerc, who found Istanbul the most interesting city in the world owing to its geographic position and its ethnic diversity, portrayed the Galata Bridge as an "ethnographic kaleidoscope" and a "real ethnographic exposition." ${ }^{85}$ But Czech travelers were primarily influenced by Hálek ${ }^{86}$ and Neruda. In his own writing Raušar cited Neruda's "poignant observation" that it is enough to

81 Svátek, Vzemi půlměsíce, 47-48.

82 Wagner, Na evropském východě, 186.

83 Svátek, Vzemi půlměsíce, 29. Wagner (Na evropském východě, 187) wrote that a wild Circassian, a sober Bedouin with a white burnus, a black man, various Europeans, as well as starving, half-naked Turkish women could all be found on the bridge.

84 Edmondo De Amicis, Constantinople, trans. Maria Hornor Landsdale (Philadelphia: The John C. Winston, 1896), 1:46.

85 According to Baskar, the description of ethnic diversity on the Galata Bridge contained also specific Habsburg features, reflecting the increased colonial ambitions of the Habsburg Empire toward the end of the 19th century. See Bojan Baskar, "Oriental Travels and Writings of the Fin-the-Siècle Poet Anton Aškerc," in Figures pionnières de l'orientalisme: Convergences européennes; Monde Anglophone, Europe Centrale et Orientale, ed. Isabelle Gadoin and Živa Vesel (Bures-sur-Yvette: Groupe pour l'Étude de la Civilisation du Moyen-Orient, 2011), 226-27.

86 Hálek emphasized that one could see representatives of all world nations on the three bridges of Constantinople. Hálek, Cestopisy, 166. 
stand for a while near the bridge over the Golden Horn to be able to see all the nations of the world, except perhaps for the inhabitants of Patagonia and Australia. ${ }^{87}$

Bill Ashcroft argues that concealed within any attempt to describe a foreign place is the ambition to "own" it. ${ }^{88}$ Yet, although knowledge is indeed associated with power, not all description is necessarily a step toward ownership. Descriptions of foreign lands served various functions, and impressing readers was not the least important of them. Pratt notes that in exploration writing, the verbal artist must take what is essentially, from a narrative point of view, almost a non-event, and make it into something of momentous significance. ${ }^{89}$ Although Czech travelers were for the most part not explorers, they used a strategy much like that employed by explorers when they tried in their own words to capture the Oriental space they were traveling through in a way that allowed them to share with the reader back home either the kinds of extraordinary places they were able to visit or the various obstacles, discomforts, and outright dangers they had to face. The former aim applied particularly to descriptions of landscapes and especially the views of Istanbul and the panorama of the Bosphorus and the surrounding nature. Hálek and Neruda once again set the tone. Their praise of Istanbul was quoted or tacitly accepted by all subsequent Czech travelers. ${ }^{90}$ Hálek claimed it was a well-known fact that as far as its location, visual charm, and the general impression it creates are concerned, "Constantinople ranks first among all the cities of Europe" (while Prague comes fourth). ${ }^{91} \mathrm{He}$ described the city as a unique garden with an extraordinarily beautiful panorama of the Bosphorus, crowned by a sense of harmony between Istanbul and its environs, making it a truly poetic city: "I saw Constantinople from every possible perspective, I saw it at sunset and sunrise, I gazed upon it in the bright light of the day and on moonlit nights, and from whatever angle I looked at it, it always appeared to me with an ever new charm and unfailing beauty..." 92

Neruda compared the view of Istanbul to an extraordinary sight, a vision impossible to describe:

87 Raušar, Na půdě sopečné, 131. See also Neruda, Obrazy z ciziny, 12.

88 Bill Ashcroft, "Afterword: Travel and Power," in Travel Writing, Form, and Empire: The Poetics and Politics of Mobility, ed. Julia Kuehn and Paul Smethurst (New York: Routledge, 2009), 231.

89 Pratt, Imperial Eyes, 202.

9o Perhaps also Byron's praise might have affected their descriptions. See Katz, The Shaping of Turkey, 93 .

91 Hálek, Cestopisy, 153.

92 Ibid., 154. 
Whatever the imagination may have conjured up about the view of Constantinople, Constantinople itself surpasses it, it does not deflate the imagination the way Rome and Paris do, but transports it to unexpected heights. Constantinople is in its own way unique, it cannot be compared to any other place. To describe Constantinople would be like writing the most wonderful poem; all of history and all of nature have made poetry here, as if the whole universe and all its sounds and color, all its forms and thoughts have converged here to create a poem..$^{33}$

Later travelers were similarly captivated by the view of Istanbul. Only one traveler, on his way to Africa in the 188 os, confessed that, having seen Istanbul on a previous trip he preferred to go to a casino, where he lost all his money and left without paying any attention to the city. ${ }^{94}$ Others considered Istanbul one of the most beautiful places in the Orient ${ }^{95}$ or even the world, ${ }^{96}$ repeating Hálek and Neruda's eulogy in similarly or less poetic words. ${ }^{97}$ They likened the silhouette of Istanbul to a poem, a fairy tale, a dream, a fantasy, or a fata morgana, ${ }^{98}$ and agreed that the city's unique location on two continents and at the crossroads of civilizations, connecting the fantastic East with the sober West, added to its attraction. ${ }^{99}$ Istanbul's charm drew from the beauty of nature, but travelers also praised its architecture, ${ }^{100}$ the mosques with their slender minarets, the marble palaces and their emerald gardens, and the quiet dignity of the Muslim cemeteries, which Byron also had admired. A number of Czech travelers, perhaps inspired by Neruda's respectful panegyric on the grave of a dervish and on the view of Istanbul from a hill above Scutari (Üsküdar), appreciated the simplicity and democratic character of Ottoman cemeteries and wrote that, compared to Christians, the Turks have a more accepting attitude toward death, which they regard as a part of life. ${ }^{101}$ One traveler

93 Neruda, Obrazy z ciziny, 8.

94 Vilém Němec, Má cesta do Afriky pres Balkán (Prague: Nákladem a vydáním Ústředního děnického knihkupectví a nakladatelství Ant. Svěcený, 1916), 68-71.

95 Klaus, Do říše půlměsíce, 176.

96 Kaminský, Návštěvou u chorého muže, 84.

97 Raušar, Na půdě sopečné, 136; Prášek, Dunajem do Cařihradu, 64-75 and 90-94; Wagner, Na evropském východě, 151.

98 Štolba, Ze slunných koutů Evropy, 14; Kaminský, Návštěvou u chorého muže, 84-85.

99 Klaus, Do řišse půlměsíce, 208; Štolba, Ze slunných koutů Evropy, 9-10; Prášek, Dunajem do Cařihradu, 76 .

100 Kaminský, Návštěvou u chorého muže, 84-85; Štolba, Ze slunných koutů Evropy, 84-94; Prášek, Dunajem do Cařihradu, 73-74 and 89.

101 Neruda, Obrazy z ciziny, 7; R. Merš, "Procházky Cařihradem: Hřbitov ve Skutari," Venkov, December 12, 1909, 1-2; Jan Tř̌šstík, Ku břehưm Adrie: Od Sarajeva do Dubrovníku (Prague: 
concluded his description of Istanbul by claiming he felt fortunate to have seen a part of this paradise on earth. ${ }^{102}$

The second strategy travelers used to add drama to the descriptions of their journey involved emphasizing the discomfort and hardships of travel, especially for those of lesser means, and underscoring or playing up the hunger, filth, and smells they encountered along the way, the narrowness of the streets, too small for their carriage to pass through, and recounting the harrowing adventures they experienced when they went off the beaten path. ${ }^{103}$ Hálek wrote an entire travel sketch on how he barely escaped being murdered when he got lost outside Istanbul and asked a couple of villagers to show him the way back at night. ${ }^{104}$ Another famous Czech writer, Svatopluk Čech (1846-1908), traveled from Istanbul to Varna on a boat and wrote that, while traveling in the third class on an Asian boat certainly has its wilder charms, it requires that the traveler have a strong spirit and excellent nerves in order to endure the brutality, the stench, the dirt, and the close proximity of other people at night: "a Breughel-like mix of bodies" that would frighten a person during the day. ${ }^{105}$ The hardships of traveling on a boat with the poor were, it seems, made more bearable if the traveler was under the cheering influence of wine. ${ }^{106}$

These visitors to the Ottoman Empire clearly had different agendas, but they all discovered the Orient they had expected. Sometimes they liked it more than they had imagined, but they tended to dwell on their suffering in order to foreground their own status as travelers.

\section{$3 \quad$ Backward or Exotic?}

According to some travelers, the difficulties of traveling were the result of the backwardness of the Ottoman Empire. As well as by boat, Svatopluk Čech also

J. Otto, 1897), 16; Štolba, Ze slunných koutů Evropy, 129-31; Svátek, V zemi půlměsíce, 192. Occasionally, a cemetery is used as a metaphor for the decaying Ottoman rule - in Serbia, for instance. See Raušar, Na půdě sopečné, 55.

102 Štolba, Ze slunných koutů Evropy, 131. Kaminský also likened Istanbul (or part of it) to an earthly paradise. Kaminský, Návštěvou u chorého muže, 84-85.

103 Dvorský and Čermák, Albánské a černohorské obrázky, 32; Guth, Letem přes řecký kraj, 137; Štolba, Ze slunných koutů Evropy, 18. Guth (Letem pres řecký kraj, 134) mentioned having to use a special powder on everything for hygienic reasons. Třeštík (Ku břehům Adrie, 15-16), in contrast, claimed that the dirt in the streets that Westerners considered an Oriental specificity had completely disappeared from Sarajevo.

104 Hálek, Cestopisy, 283-93.

105 Svatopluk Čech, Upomínky z Východu: Obrázky z pouti po Kavkaze a z cesty zpáteční (Prague: Nakladatelství F. Šimáčka, 1885), 186-87.

106 Jiř́í, K pyramidám, 6. 
traveled by train. Commenting ironically, Čech recounted that it was supposed to be a fast train, but it dragged, and it had no carpets or pillows and had probably been brought to Turkey after a well-deserved retirement in Britain. He nevertheless acknowledged that Turkish railways had to overcome many obstacles, from the population's resistance to new things to collisions with buffaloes on the tracks. ${ }^{107}$ Raušar thought that the old trains he saw were ones that had been put out of use in Germany or Austria, but seemed good enough for the Turks. ${ }^{108}$ Travelers also commented on how out of date the Ottoman military equipment, arms, and ships seemed to them. While the writer and journalist Karel Mečír, writing under the pen name Merš, described this in neutral terms and without condescending remarks, ${ }^{109}$ Svátek took the state of the armed forces as a symbol of the whole "Turkish economy" and remarked that the soldiers were probably so used to it that they had ceased to be ashamed. ${ }^{110}$ Nevertheless, the railway, though newly constructed or under construction, seemed a particularly apt symbol of the backwardness of the Ottoman Empire. Josef Kořenský, an explorer who traveled through Ottoman territory, stated that "Old Asian Turkey" never prided itself on its order and security, or particularly on its public roads, and it was up to foreign entrepreneurs to build the railways. "As long as the Turkish government was itself trying to arrange the construction [of the railway] to Ankara, the project did poorly, but as soon as German capital took over the task, the work started to progress, and in November 1892 the first train left for Ankara via Eskishehir."111

Ussama Makdisi distinguishes several stages in the Western relationship to the Ottoman Orient. The first stage was represented by an early romantic escape from European modernization to the very different and exotic Orient. This gave way to the pragmatic notion that the Orient needed to be modernized along Western lines. This was sometimes followed by a neo-romantic reaction to the Orient's own attempts at modernization. In Makdisi's words, the West responded to the way the Ottoman Empire challenged the idea of dividing the world into the premodern East and the modern West by rejecting the possibility that there could be any local form of modernity and defending the pristine Orient from its Oriental modernizers, which was often accompanied by claims of Europe's cultural and racial superiority. ${ }^{112}$ Duncan and Gregory somewhat differently contrast the early stage of romantic travel and its passion for wilderness, cultural difference, and a desire to be immersed in local

\footnotetext{
107 Čech, Upomínky z Východu, 198-99.

108 Raušar, Na pưdě sopečné, 124.

109 R. Merš, "Procházky Cařihradem: Po Zlatém Rohu v ř́ínu," Venkov, November 3, 1909, 1-2.

110 Svátek, Vzemi půlmèsíce, 9-10.

111 Kořenský, Asie, 209.

112 Makdisi, "Mapping the Orient," 41-42.
} 
color, in a time when travel was slow, unregimented, and solitary, with the later part of the 19th century when "the sheer number of tourists present in some places made the illusion of discovery, or even immersion in the local, harder to sustain. The romantic's idea of an unsullied world was replaced by the image of a world overrun by industrialism."113

Czech travelers only started to discover the Ottoman Orient on a larger scale in the last third of the 19th century and thus harbored a mix of these European views. Every type of attitude toward the Orient identified by Makdisi and Duncan and Gregory could be observed in Czech writing at the same time - in the late 19th century - or even in the work of a single author a specific blend of these views might be found. Kořenský, as we saw, considered modernization to be successful only when it was implemented by foreign, German, capital.114 Klaus, in contrast, had mixed views about modernization, praising it in the Balkans and when achieved by the Balkan Slavs, but expecting the Orient, namely Istanbul, to remain Oriental. However, rather than advocating European superiority, he criticized the European impact on the Ottoman Orient. Furthermore, some travelers also welcomed modernizing efforts that did not come from the West (or the Slavs): Klaus expressed his appreciation of the art school that was established in the 1880 s by Hamdi Bey (Osman Hamdi), which he considered a turning point away from the old ways that had been completely defined by Islam. By the time of his visit, the school had 200 students, most of them Turks, studying painting and sculpture. ${ }^{115}$ Merš, who condemned the state of the Ottoman army's equipment, in another article wrote positively of his experience meeting young graduates of a new police school at Yildiz (Yıld $ı$ ) in their new uniforms, who were serious and impeccable in their appearance, and respectful and reserved in their behavior. ${ }^{116}$

Ottoman backwardness was often contrasted with the modernity of the West, whose railways and electricity, in Svátek's words, brought light into every dark corner of the Ottoman Empire. ${ }^{117}$ In the 189os, Guth used a similar contrast for Izmir - a city both modern and barbarian at the same time, with its old Turkish neighborhoods and a modern European cosmopolitan area where "the West, represented by the tramway ... touches the East, which in long, slow

\footnotetext{
113 Duncan and Gregory, "Introduction," 6-7.

114 Kořenský, Asie, 209.

115 Klaus, Do řiše pưlměsíce, 262. The school was Sanayi-i nefise mekteb-i, founded by the famous Ottoman painter, archeologist, art historian, and museum curator Osman Hamdi Bey $(1842-1910)$.

116 R. Merš, "Slavnostní jízda k zahájení druhého zasedání parlamentního v Cařihradě," Venkov, November 23, 1909, 1.

117 Svátek, Vzemi půlměsíce, 24.
} 
caravans of camels strung together marches in single file across the tracks of the tramway, bringing for a few moments the feverish advancement of our civilization to a halt ..."118 While travelers mostly sided with the progress brought by the West, given the feverish advancement of Western civilization (or, in Duncan and Gregory's words, the "world overrun by industrialism"), the slow pace of the Orient did not seem to be such a bad thing.

The contrast between Western modernity and Eastern backwardness appeared as a side note in many travelogues. It was prominent in travel accounts of journeys through the Balkan countries that had recently been emancipated from Turkish rule; in these countries, the Ottoman heritage was associated with backwardness and juxtaposed with the positive changes brought about by the independent states. Klaus described the disappearance of the Oriental character of the Bulgarian Rushchuk after the Turks moved away. Rushchuk quickly recovered, especially its Bulgarian neighborhood, with its commerce and schools, bookstores and printing press, not to mention its beerhouses. The Turkish neighborhood, by contrast, was poor, and although it had twenty camis (mosques), its streets grew deserted as the Turks moved away, and the town began to lose its Oriental features and to acquire a Western character. ${ }^{119}$ Similar remarks appeared in descriptions of other Balkan countries, including Albania ${ }^{120}$ and Serbia. Raušar observed that in Belgrade and Nish, the physical appearance of the dirty old Turkish towns, with their curvy empty streets and shabby Eastern houses, was being lost to broad avenues and beautiful buildings. ${ }^{121}$ The backward/modern dichotomy was sometimes extended to depictions of the changing power relations and the position of the Turkish and local, Slavic, populations vis-à-vis each other. Prášek, and Klaus after him, commented on the changing hierarchy: the previously subjugated Bulgarian was now an officer and represented the official authorities, while the barefoot Turkish porters bowed beneath the heavy loads they had to carry. ${ }^{122}$ More generally, in the Balkans, purportedly Slavic traits (clean, organized, neat, rapidly developing, and modernizing) were contrasted with allegedly Turkish attributes (dirty, picturesque, backward, and decaying). ${ }^{123}$

The link between backwardness and modernity was also conceptualized in temporal terms: Svátek described his travel along the coast of Asia Minor to

\footnotetext{
118 Guth, Letem přes řecký kraj, 135.

119 Klaus, Do říše půlměsíce, 138.

120 Dvorský and Čermák, Albánské a černohorské obrázky, 4 and 25.

121 Raušar, Na pưdě sopečné, 50.

122 Prášek, Dunajem do Cařihradu, 46; Klaus (Do řǐše půlměsíce, 129-30) uses the same image and almost the same words.

123 Raušar, Na půdě sopečné, 50.
} 
Istanbul and further West as a trip from the past into the present and toward a brighter future - although it remains unclear where this bright future was coming from. ${ }^{124}$ Knotek reflected that in the Ottoman Balkans "[e]verything is keeping pace with the times. The situation on the Balkan Peninsula cannot be solved at once, development is necessary here. West European progress and civilization even here, on this hot land, are slowly making their way toward the liberation of the nations that are groaning under the yoke of the Turkish Empire."125

The development was not always linear, nor was it always welcome. The disappearance of Oriental features was seen by some writers as a genuine loss and made them nostalgic for the past. Klaus, who applauded the passing of the Oriental heritage in Bulgaria, saw it differently when it concerned Istanbul, the "real" Orient:

Yet even here, the poisonous breath of the West seeps at least as far as the shores of the Golden Horn and particularly to the suburb of Pera, and it has the young Turks especially in its grip. They have long set aside their local attire and donned our tailed coats, they have long ceased to meet here in simple coffee houses, in imitation of their ancestors, [and] instead they gather in West European wine cellars, beerhouses, chantans, and gambling houses around a table on which a disgusting card game begins... Constantinople is changing quickly, but to its detriment; everything is undermined by European civilization, with all its passions, and with its public sale of bodies and alcohol, the effects of which are as damaging here as they are in our countries. The Stambul lanes still stand strong, but how long they will endure, God knows... And it will be a great pity [when they are gone] as something poetic emanates through them, especially in the evening, when everyone, particularly the old-believers in white and green turbans and long caftans, rushes to the mosque. ${ }^{126}$

Eight years later, Štolba commented upon the retreat of the East and the growing influx of the colder "European blood," and urged Czech tourists to "hurry up if you want to see Turkish Istanbul."127 Czechs were like other tourists who,

\footnotetext{
124 Svátek, Vzemi pưlměsíce, 244-45.

125 A. Knotek, Balkán: Poměry v Makedonii (Most: O.J. Bukač, n.d., ca. 1909), 5. Dvorský and Čermák found one of the few differences between Catholics and Muslims in Skadar to be that the former were more open to progress (and to Austrian visitors). Dvorský and Čermák, Albánské a černohorské obrázky, 32-33.

126 Klaus, Do ř́še pưlměsice, 198-99.

127 Štolba, Ze slunných koutů Evropy, 68.
} 
as Gregory noted about travelers to Egypt, had to be reassured that modernity had not yet destroyed the very object of their journey and that "the Orient," as they had imagined it, was still there for them to explore. ${ }^{128}$

The same image could be used by different authors or in different contexts as proof of backwardness, or as a sign of the romantic, exotic East. A curvy street, as a remnant of the past, could be presented as either an obstacle for modern travelers or a picturesque setting for European visitors to stroll through. Complaining about the lack of comfort or emphasizing how bravely they had coped, travelers sought out the most different and exotic sites. They drew attention to the variety of smells and colors, multifacetedness of the architecture and the diversity of the people, and the fairy-tale or dream-like character of the places they visited. The exoticism of the Ottoman Empire was further evoked by inserting Turkish words in the text. Almost every travel account contained at least some Turkish words. Next to baksheesh, harem, and bazar, the most common words were terms used to refer to different kinds of people, such as "kadun" (kadin, i.e. woman) and "effendi" (sir), professions ( $h a-$ mal, porter), items of clothing (Turkish yaşmak, veil, transcribed in Czech writing as jašmak, or terlik, slipper), and idioms (in Turkish çok yaşa, in Czech as čok jaša, Long live!). Some travelers even included whole Turkish sentences and sayings, ${ }^{129}$ often reproduced incorrectly or in garbled form, to underline the Oriental atmosphere and demonstrate their own "expertise" as a traveler the translator of a distant culture. ${ }^{130}$

As well as the exotic, travelers also looked for things that reminded them of home. They almost always mentioned meeting Czech immigrants and other Czechs who were working in or traveling through the Ottoman Empire - for instance, some Czech teachers employed in the Sultan's harem. ${ }^{131}$ Those who traveled in the early 2oth century highlighted, among Istanbul's attractions, the dragoman (interpreter) Mr Vincenc Zámečník, their "guardian angel" and

128 Derek Gregory, "Scripting Egypt: Orientalism and the Cultures of Travel," in Duncan and Gregory, Writes of Passage, 119 .

129 Wagner, Na evropském východě, 152; Kaminský, Návštěvou u chorého muže, 48; Schwarzenberg, Pod praporem, esp. 22. Unlike many other travelers, Schwarzenberg (40) admitted that his Turkish was poor.

130 One of the first Czech Middle Eastern scholars, Jan Rypka, who wrote a series of articles about Istanbul during his stay there in 1922, also included in his writing Turkish phrases and excerpts from poems in Turkish (with their Czech translations). The Turkish was of course correct, but Rypka chose similarly exoticizing images of Istanbul as other travelers; for instance on the superstitiousness of the Turks he wrote: "there is still much in the way of superstition in Stambul and perhaps all the Orient..." Jan Rypka, "Z Cařihradu," Národní listy, March 30, 1922, 1 .

131 Hálek, Cestopisy, 158. 
compatriot who helped them to get acquainted with life in the Ottoman capital and showed them around the city. ${ }^{132}$ The travelers always looked up Czech businesses, hotels and restaurants and never failed to mention any Czech products they came across, ${ }^{133}$ most notable among these being the $f e z$ - as fezes were manufactured in Southern Bohemia. ${ }^{134}$ Hálek devoted a lot of attention to describing the compatriots he encountered in Istanbul; he remembered with particular gratitude a Czech restaurant in the city and even described the Czech dish it served during his visit. ${ }^{135}$ One of the oddest "patriotic" references is found in Guth's 1896 account of his trip: in a bar in Smyrna (Izmir), Guth noticed that the young women working there reminded him of Bohemian factory girls, and, indeed, the "chanteuses" at the bar turned out to be Czech. Guth wrote that they were dressed like Czech working-class girls and there was generally nothing offensive about their behavior. But, with a sigh he added, "[t]he whole East is flooded with these 'German' singers who even here everyone knows are from Bohemia, and the Czech lion must roar in pain when he recalls how little these dear children of his contribute to his honor and glory..."136

Duncan and Gregory compare travel to translating and argue that translation is performed either using "a domesticating method," which adapts the foreign text so as to accommodate the target language's cultural values and thus brings the author back home, or "a foreignizing method," which registers the linguistic and cultural differences of the foreign text and sends the reader abroad. ${ }^{137}$ Czech travelers used both methods: on the one hand, they exoticized their narratives by employing Turkish words or stereotypical Oriental images and, on the other hand, they domesticated their observations from abroad. They likened what they saw in the Ottoman Empire to familiar sites at home in order to bring them closer to the reader. A villa suburb of Istanbul reminded Kaminský of the outskirts of Prague, writing that it was as if the Czech town of Řevnice near Prague had been transplanted to suburban Istanbul. ${ }^{138}$

132 Svátek, V zemi půlměsíce, 38; Merš, "Procházky Cařihradem: Po Zlatém Rohu v říjnu," 1; Kaminský, Návštěvou u chorého muže, 44; Václav Moravec, Cesta do Orientu (Prague: printed by author, 1925), 125 .

133 Hálek, Cestopisy, 156-58 ; Svátek, Vzemi půlměsíce, 4; Klaus, Do říše půlměsíce, 184; Máša Absolonová, "Přes hranice Černé Hory," Ženský svět, December 20, 1912, 305; Merš, "Procházky Cařihradem: Po Zlatém Rohu v ř́ínu," 1; Kaminský, Návštěvou u chorého muže, 59; Čech, Upominky z Východu, 195; Štolba, Ze slunných koutů Evropy, 184.

134 Svátek, Vzemi pưlměsíce, 4; Guth, Letem přes řecký kraj, 143; Kaminský, Návštěvou u chorého muže, 59 .

135 Hálek, Cestopisy, 157-58.

136 Guth, Letem prè řecký kraj, 139-41.

137 Duncan and Gregory, "Introduction," 4-5.

138 Kaminský, Návštěvou u chorého muže, 43. 
A post office on the Asian shore of Istanbul resembled, according to Štolba, some of "our post offices, especially the rural ones."139

Sometimes there was a critical objective behind the comparisons made with Czech places and phenomena. A comment on the lack of a reading culture or any booksellers in Istanbul ${ }^{140}$ was clearly meant to show the superiority of the Czechs; interestingly, according to one traveler, even in carpet weaving the Czechs were almost as good as the Turks. ${ }^{141}$ Although the Turks mostly came out unfavorably in these comparisons, there were cases in which they were presented as a model for the Czechs. ${ }^{142}$ Kaminský ironically contrasted the Turks' "uncivilized" policy toward tenants, which gave the tenants more rights, to the "civilized" Czech practice that allowed women and children to be thrown out of their home and onto the street. ${ }^{143}$ He even portrayed the constant presence of baksheesh as having some positive aspects - at least it is open and clear, whereas the Czechs expected bribery, too, but concealed it behind various other names they had for it. ${ }^{144}$ Štolba admired the craftsmanship of Muslim stonecarvers, whose work at the cemeteries he found infinitely superior to the Czech variety, and deemed Turkish cemeteries more egalitarian than those at home. ${ }^{145}$ According to Bracewell, praise of the Ottoman Empire in East European travel accounts was commonly used as a way of criticizing something in the home society ${ }^{146}$ and sometimes a similar purpose could be discerned behind the admiration for Ottoman practices expressed by Czech travelers. It is interesting how much Czech travelers nevertheless insisted on the essential differences between the Ottoman Empire and Europe.

In Czech, the contrast between the Ottoman Empire and Europe assumed two forms: the term Orient or East (Orient, východ) often had exoticizing or fairy-tale connotations, while, when dealing with the political situation and the position of the Ottoman Empire from an international prespective, Czech travelers tended to locate the Ottoman Empire in Asia and emphasize its Asian character. Svátek argued that Ottoman rule brought Asian culture to Constantinople and the Turks then extended that culture to Europe through their brutal occupation, implying that the Turks had no place in Europe and would be

\footnotetext{
139 Štolba, Ze slunných koutů Evropy, 124.

140 Ibid., 101.

141 Guth, Letem přes řecký kraj, 147.

142 Klaus, Do ř́śse půlměsíce, 198 and 223.

143 On this and other examples of Ottoman habits being deemed superior to Czech practices see Kaminský, Návštěvou u chorého muže, 104-8.

144 Ibid., 177.

145 Štolba, Ze slunných koutů Evropy, 51.

146 Bracewell, "The Limits of Europe," 78.
} 
expelled from it. ${ }^{147}$ Wagner wrote that the Asian "heathens" were always crossing the Bosphorus to try to expand and battle their way into Europe, and he associated Asia primarily with fanaticism. ${ }^{148}$ Or, as Štolba put it, visitors to Constantinople witnessed a constant and quiet fight between "the brutal, fanatical, and sterile violence of the Asian East and the European West, procreative in the cultural sphere," a fight that had already been decided in favor of the West. ${ }^{149}$ A trip to Izmir brought Guth to Asia, "from where terrible winds and storms swept over Europe, from the Tatar invasions to the river of Chinese that threaten to overwhelm Europe in the future." ${ }^{150}$ For other writers, too, an important distinction was between Asia, often as the home of barbarian tribes ready to invade Europe, and Europe, rather than between the Orient (or East) and the West. ${ }^{151}$ In this juxtaposition, the Czechs are naturally considered a part of modern Europe, sometimes implicitly, often explicitly, but without emphasizing the point in any special way, as when the authors refer to "our" European ways and languages or speak about "European travelers" and clearly mean themselves. ${ }^{152}$

\section{Turkish Men (To Say Nothing of the Dogs)}

The Bosphorus, which connects Europe and Asia, offers breathtaking visual splendor on a narrow strip of land, wrote Svátek in 1909. But, he added, these natural marvels had done nothing to refine the men who live surrounded by this beauty, nor had it inspired them to achieve higher aims. It was, he said, hard to believe that these gorgeous flowered slopes could give birth to a people who delighted in "flowers of blood" and the "groans of the tortured." 153 The contrast between the country's nature and its people that authors from many countries alluded to is particularly striking in Hálek's travel account. Hálek concluded his description of how magnificent Istanbul appeared on the outside with harsh condemnation of what was inside the city: "All this applies to its external

147 Svátek, Vzemi půlměsíce, 24 and 79.

148 Wagner (Na evropském východě, 189) mentions fanaticism in relation to a performance of dervishes that he saw in Scutari.

149 Štolba, Ze slunných koutů Evropy, 68.

150 Guth, Letem pres řecký kraj, 128.

151 Klaus (Do řišse pưlměsíce, 160) described the Danube as a natural divide between Asia and Europe, a route of commerce and of barbarian inroads to the heart of Europe - the Huns and then the Turks, who had gotten close to the Czech borders.

$15^{2}$ Klaus, Do ř́šse pưlměsíce, 165; Kaminský, Návštěvou u chorého muže, 105 and 117-18.

153 Svátek, Vzemi půlměsíce, 201. 
appearance. It is a different matter on the inside. People say that if one does not want to spoil one's illusion of Constantinople, one should never even enter the city."154 He notes that Alexandre Dumas on one of his visits allegedly spent several days looking at Constantinople - from a boat, never disembarking. He likens Constantinople to a person endowed with sparkling spiritual and physical charms, to which everyone is attracted at first sight. But it is a person without morals, distinguished by excesses and vices that repel the viewer. "For Constantinople's beauty is not artificial, it is not false; she is so rich in nature itself that she can feel like a queen among her companions; but on the inside she manifests such a dearth of all taste, such utter decreptitude, that one stands before her as astonished as one was a moment before by her beauty."155 Hálek's successors often felt compelled to reproduce this contrast that he made, but without Hálek's strong condemnation of the city and the Turks. ${ }^{156}$ Štolba, for instance, presented the beautiful appearance of Istanbul in opposition to its dirt and smell, which he found typical of the Orient as a whole, but he hastened to add that visitors to Istanbul would immediately find more than enough compensation in watching the life that unfolds on the smelly streets. ${ }^{157}$

Travelers' opinions of the Ottoman Turks clearly varied and at times seem confused or contradictory. This is reflected in the terms that the Czechs used to refer to the Turks: the neutral designations included Turks (which was sometimes employed also for other Muslims of the Empire), ${ }^{158}$ Ottomans (Osmani, Osmanlı) ${ }^{159}$ and various forms of Muslims (muslimové, moslemíni, mahometáni, mohamedáni):;60 occasionally, all these terms appeared side by side, even in works by authors who demonstrated considerable knowledge of the history and origins of the Ottoman Turks, ${ }^{161}$ suggesting that the confusion was not necessarily a matter of ignorance, but resulted from a lack of interest in using precise terms. Other words had judgmental connotations, such as the somewhat

154 Hálek, Cestopisy, 155 .

155 Ibid., 156.

156 Jiř́k (K pyramidám, 75) said in 1913 he was glad to be leaving Egypt - a country full of natural beauty and wonderful monuments, but inhabited by annoying and obtrusive people, constantly asking for baksheesh.

157 Štolba, Ze slunných koutů Evropy, 18.

158 The term "Turk" included also the Muslim Slavs of the Balkans who were also called Turčíni. See Knotek, Balkán, 44; Antonín Zavadil, Obrázky z Bosny: Trappisti - Turci - Židé cikáni (Prague: Nákladem Josefa Pelcla, 1911), 28 and 32.

159 Svátek, Vzemi půlměsíce, 24; Rüffer, Válka rusko-turecká, 3, 125, and 561; in another context also Mayerhofer, Ilustrovaná kronika, 110.

160 Kořenský, Asie, 208; Svátek, Vzemi půlměsíce, 41; Klaus, Do ř́iše půlměsíce, 224-25. See also Mayerhofer, Ilustrovaná kronika, 110.

161 Svátek, Vzemi půlměsíce, 100-105, 41, and 52. 
derogative Turčini, ${ }^{162}$ a name that referred to both Muslim Slavs and Ottoman Turks. Often, the writer's negative stance was expressed by the use of the singular form Turek (the Turk) in instances where the meaning called for the plural. ${ }^{163} \mathrm{~A}$ less common diminutive form of this word, Tureček (little Turk) did not necessarily express hostility, but it did imply a sense of superiority on the part of the speaker. ${ }^{164}$

Although Czech travelers accepted the views about non-Europeans that had been formulated by European philosophers and intellectuals in the previous centuries, their travel accounts did not reflect some of these earlier ideas - for instance, on the impact of climate on the character of the country's inhabitants - perhaps because Czechs did not start traveling to the Ottoman Empire in larger numbers until the second half of the 19th century. They also paid little or no attention to two phenomena that had figured prominently in European views on the Ottoman Empire and often survived in Western travel literature throughout the 19th century, namely the despotic character of Ottoman rule and Ottoman slavery. ${ }^{165}$

Czech travelers were certainly not immune to the influence of older stereotypes, especially the ones that were stoked back to life in Czech anti-Turkish pamphlets in the 1870 . They called the Turks hostile, and they claimed that the Turks see an enemy in every stranger, and even when polite and obliging they remain suspicious of foreigners. ${ }^{166}$ Travel writers commonly referred to the Turks' violence and cruelty, ${ }^{167}$ sometimes in almost absurd circumstances: Čech described how he watched some proud scribes, with a spiritual mien, holding containers filled with ink, which, he wryly remarked, had not been spilt in the land of the Padishah as much as blood had been. ${ }^{168}$ In spite of the general decline in Ottoman power, many travelers agreed that the position of the Turks in the Ottoman Empire still made them haughty and complacent,

\footnotetext{
162 Knotek, Balkán, 44.

163 Hálek, Cestopisy, 167, 179, and 195; Zavadil, Obrázky z Bosny, 28; Kaminský, Návštěvou u chorého muže, 6o, 80, 100, and 105.

164 Kaminský, Návštěvou u chorého muže, 48, 67, and 103.

165 On the impact of these ideas in the West see Çırakman, European Images of Ottoman Empire, 132-56; Schiffer, Oriental Panorama, 186-90, 234-40, 308-17; Melman, Women's Orients, $145-48$.

166 Svátek, Vzemi půlměsíce, 103.

167 Wagner (Na evropském východě, 174) described how he watched, while sitting in a café, as an Englishman was stabbed and robbed on the street. Štolba (Ze slunných koutů Evropy, 55) called the murder of a sultan a common Turkish habit. Kaminský (Návštěvou u chorého muže, 89) wrote in the same vein about Abdülhamid who, when he murdered his brother, was, claimed Kaminský, only following an old habit of his ancesstors.

168 Čech, Upomínky z Východu, 190-91.
} 
and, some travelers claimed, this was reflected in a saying that attributed beauty to the Circassians, trade and wealth to the Greeks and Armenians, science to the Europeans, but stateliness to the Turks. ${ }^{169}$ Comments about the Turks' lust were often directed at the past, and lust was regarded as a symbol of Ottoman rule, not only over women but also over the Balkan peoples. ${ }^{170}$ Most accusations of fanaticism that appeared in various travelogues also referred to the past; now, Raušar explained, the Turks' fanaticism had become milder. ${ }^{171}$ Old stereotypes had a long life: jannissaries represented the atrocious past of the Turks, when they were responsible for the widespread image that emerged of the Turk as bloodthirsty, violent, and vengeful - an image that unfortunately, Svátek noted, had survived into the present, even though the source of the bloodshed had vanished. ${ }^{172}$ Gradually, the old stereotypes were disappearing, but were giving way to new ones.

Writing about the Turks they actually met, Czech travelers complained most about their "corruption" and the constant expectation of baksheesh. ${ }^{173}$ Gregory has noted that around roughly the same time tourists in Egypt were grumbling about the local population's demands for baksheesh and increasing ability to take financial advantage of visitors. ${ }^{174}$ The Czechs shared the double standard of the British travelers who saw nothing wrong in getting a bargain, but criticized the local population for trying to do the same. Some Czechs, however, found the experience entertaining and illuminating and considered it a cheap way of solving problems. ${ }^{175}$ Most travelers also described the Turks as lazy, apathetic, indolent or sleepy, ${ }^{176}$ but sometimes did so with a degree of sympathy or even envy. They found their relaxed attitude contagious and noted that it

169 Svátek, Vzemi půlměsíce, 102; Kořenský (Asie, 207) quotes the same proverb. Guth (Letem pres řecký kraj, 154) described this attitude as the complacent dignity of a mighty host.

170 Such comments often appear in reference to the Turks' interest in Slavic women in the Balkans. See Knotek, Balkán, 40. According to Raušar (Na půdě sopečné, $5^{2}$ ), such behavior manifests how terrible Turkish rule "used to be."

171 Raušar, Na pưdě sopečné, 132.

172 Svátek, Vzemi půlměsíce, 68-69.

173 Kaminský, Návštěvou u chorého muže, 34, 47, 49, 53, 73, 127, 148, and 177; Hálek, Cestopisy, 167; Svátek, Vzemi půlměsíce, 26-27; Klaus, Do říše půlměsíce, 187; Raušar, Na půdě sopečné, 138; Knotek, Balkán, 13 and 29-33; Wagner, Na evropském východě, 156-57; Štolba, Ze slunných koutů Evropy, 41.

174 Gregory, "Scripting Egypt," 124.

175 Guth, Letem přes řecký kraj, 132.

176 Svátek, Vzemi půlměsíce, 103; Guth, Letem přes řecký kraj, 129 and 133; Wagner, Na evropském východě, 163 and 177; Čech, Upomínky z Východu, 190; Klaus, Do řiše půlměsíce, 19798; Raušar, Na půdě sopečné, 136; Dvorský and Čermák, Albánské a černohorské obrázky, 38-39. 
made people happy. ${ }^{177}$ The Turks were also depicted as uneducated, resistant to change, and unable or unwilling to accept progress. ${ }^{178}$

Similar characteristics were ascribed to the Turks by other European visitors to the Ottoman Empire. Like other European travelers, the Czechs distinguished city-dwellers from villagers and occasionally discovered what they called "true" Turkishness among the Anatolian people, unspoiled by civilization. But since only a small number of Czechs traveled more extensively in Anatolia, comments like these seem to have been drawn more from Western writings, rather than being the authors' own observations. Although some Czechs praised the egalitarianism of Turkish society, ${ }^{179}$ class did not figure prominently in Czechs' reflections on the Ottoman Empire, unlike, according to Schiffer, those of British travelers, for whom " $t$ ] $]$ he description along the demarcations of class was certainly the one most commonly applied." 180 Furthermore, compared to British travelers, Czech authors did not pay much attention to the physical appearance of Turkish men, and certainly did not write about the Turks' beauty, dignity, and resemblance to ancient figures. ${ }^{181}$ Scholars see the reasons for the Turkophile positions of 19th-century British travelers as lying in their sense of commonality with the Turks as "an ancient imperial race," with whom the British shared such characteristics as being stoic and taciturn, as well as in a declining sympathy for the Greeks after they gained independence. ${ }^{182}$ The Czechs, who had no imperial past, at least not one they could easily identify with, did not feel a similar kinship with the Ottoman Turks.

Nonetheless, the Czechs who visited the Ottoman Empire did not see the Turks as an undifferentiated and unchanging group. They found some Turks more like Europeans than others. They distinguished the "old-Turks" uneducated, backward, and clinging to Islam - from the "new-Turks," whom they described as modern, educated, and open to progress and to foreigners. Svátek made a distinction between the "very advanced intelligentsia" and the

177 Dvorský and Čermák, Albánské a černohorské obrázky, 38-39; Klaus, Do ř́še půlměsíce, $197-98$.

178 Svátek, Vzemi půlměsíce, 103; see also Neruda, Obrazy z ciziny, 9; Wagner, Na evropském východě, 163 .

179 Most notably Klaus, Do řiše půlměsíce, 223. Svátek (Vzemi půlměsíce, 55) noted the nonexistence of nobility in the Ottoman Empire. Others wrote approvingly about the egalitarianism of Turkish cemeteries; see, e.g., Štolba, Ze slunných koutů Evropy, 51.

180 Schiffer, Oriental Panorama, 245; on views about social fluidity in Ottoman society see also Heffernan, "Traveling East," 159.

181 Schiffer, Oriental Panorama, 242-45.

182 Ibid., 243-50; Nash, "Politics, Aesthetics and Quest," 59-6o. 
average uneducated Turks, who just dreamed about "kéf" (keyif, i.e. bliss) and spent their time in coffee houses and mosques. ${ }^{183}$ Wagner contrasted the "oldTurk" fanatics with a "new-Turk" bookseller ready to sell books to nonbelievers, and found similar distinctions even among sultans - namely, between the "old-Turk" Sultan Abdülhamid and the modernizing Sultan Murad. ${ }^{184}$ Thus, while the Turks as a whole seemed backward compared to the Europeans, including the Czechs, individual examples of "enlightened" Turks as well as references to "the spirit of time and progress," which affected even the Turkish censors, ${ }^{185}$ suggest that the Turks were not considered unfit for modernization and progress.

A frequently mentioned obstacle on the path to progress was Islam, at least amongst those Muslims who were too devout. Statements about how Islam leads to fatalism, prejudice, and hostility to non-believers were still appearing in travel accounts published around the turn of the century. ${ }^{186}$ Kaminský wrote about Islam (and most other topics, including Czech customs) in tones of contempt and ridicule: he expressed a mocking admiration for the imagination of Muslims, who believe that an angel in Paradise has a million heads with which to praise Allah, and who thank Allah for not giving camels wings. ${ }^{187}$ Štolba wrote in the same spirit that Muslim hell is better than ours because even the worst peccant will, after he is punished, enter Paradise, where all the beautiful houris are; he moreover ridiculed the notion that women cannot enter Paradise, although some animals can. ${ }^{188}$ Most travelers, however, had ambiguous views of Islam and appreciated at least some of the principles and behaviors of its followers. ${ }^{189}$ Neruda wrote admiringly about the grave of a dervish that he saw: "[w] hat a man he must have been, so matured by his solitude, so refined

183 Svátek, Vzemi pưlměsíce, 104. Also Kořenský (Asie, 212) points out "more enlightened" men among the average phlegmatic Turks.

184 Wagner, Na evropském východě, 154 and 162. Sultan Murad v (1876) was the brother and predecessor of Abdülhamid II, who was considered liberal, but was deposed after just three months on the throne on the grounds of his mental illness. Raušar (Na pưdě sopečné, 53-54) described the head of the local Turkish community in Leskovec, which had remained in Serbia after 1878, as a "European man," dressed in European clothes (apart from the fez), enlightened, not prejudiced, and open to foreigners.

185 Knotek, Balkán, 21.

186 Kořenský, Asie, 207; Svátek, Vzemi půlměsíce, 103.

187 Kaminský, Návštěvou u chorého muže, 58. Also Hálek (Cestopisy, 334) described a praying Muslim as performing comical exercises, which made many observers laugh.

188 Štolba, Ze slunných koutů Evropy, 49-50.

189 Even Hálek was sometimes impressed by the seriousness with which Muslims prayed, but he noted that not everybody was so devote, pointing to the vendors who pursued believers even inside mosques. Hálek, Cestopisy, 177. 
under the constant effect of a sublime scene [the view of Constantinople]!"190 Later travelers respectfully described Muslim funerals, ${ }^{191}$ the Muslims' devotion and observance of religious duties, ${ }^{192}$ and the positive effect Islam had on the Turks' character and its encouragement of good deeds. ${ }^{193}$

Although some authors expressed a consistently negative or positive opinion of the Ottoman Turks, most travelers' views were more equivocal and mixed. Neruda, for instance, wrote that "the Turkish period was not worse than the Byzantine times, the Turks have never defiled graves, church vessels, etc., as did the Latins themselves, who took dead bodies from the crypts and let their horses drink from chalices - but history marches quickly onward and the Ottoman walks slowly."194 Others noted that many of the shortcomings ascribed to the Turks could also be found among other peoples but were perhaps just less obvious, and they argued that one ought not to make generalizations about the awfulness of Turkish administration based on a single observation. ${ }^{195}$ Czech visitors to the Ottoman Empire, like travelers from other countries, recognized that the Turks had some good qualities. They praised Turkish hospitality ${ }^{196}$ and the unobtrusiveness of Turkish shopkeepers. ${ }^{197}$ Jan Wagner, writing in the 1880s, applauded the Turks' willingness to accept refugees and argued that this, and the Turks' tolerance of minorities, could serve as an example for many "civilized nations." 198

Perhaps the most positive image of the Turks was painted by Klaus. He described the social life of the Turks as much friendlier, more intimate, and more sincere than what he knew at home, and portrayed their social relations as free from class hierarchies and hereditary nobility (there was no such thing as an aristocrat by birth!). He deemed Turkish society to be less awash in hypocrisy, deceit, and falsehood than its Czech counterpart, and the Turkish people more just, charitable, and hospitable in character. And he felt they were also more

190 Neruda, Obrazy z ciziny, 7.

191 Merš, "Procházky Cařihradem: Hřbitov ve Skutari," 2.

192 Svátek, Vzemi půlměsíce, 41.

193 Klaus, Do ř́še půlměsíce, 224-26.

194 Neruda, Obrazy z ciziny, 9.

195 Guth, Letem přes řecký kraj, 129 and 133; Kaminský, Návštěvou u chorého muže, 104-8 and 117-18. See also Schwarzenberg (Pod praporem tureckého půlměsíce, 82) for a somewhat different comparison between Europeans and the inhabitants of the Ottoman Empire.

196 Guth, Letem přes řecký kraj, 154; Wagner (Na evropském východě, 183) noted that it is most strongly felt in "pure," unmixed Turkish areas. Svátek (Vzemi půlměsíce, 103) was more ambivalent; he wrote that the Turks are perfect in hospitality, but that does not mean they relinquish their fear of foreigners.

197 Štolba, Ze slunných koutů Evropy, 101; Klaus, Do ř́šse pưlměsíce, 223-24.

198 Wagner, Na evropském východě, 193-94. 
content. Isn't the carefree enjoyment of a cup of coffee better than drinking spirits in our pubs?, he asked. ${ }^{199}$ In these instances praise of the Turks was coupled with criticism of the Czechs, but not all such praise contained a message directed at the society back home. Klaus attributed many of the Turks' good qualities, such as trustworthiness, to the rules of the Koran, which touches on not just religious, but also everyday concerns, and which the Turks observed to the letter, ${ }^{200}$ and he highly praised the Turks' charity, care for the poor, and love of animals. ${ }^{201}$ Although his work was not free from stereotypical views and a sense of nostalgia for traditional society as well as occasional criticisms of the Turks, he seemed to be motivated by a genuine interest in "the Orient." According to his own words, he wrote his travel book in order to inspire young Czechs to travel to the Orient, get to know it, and become its lifelong friend. ${ }^{202}$

Klaus praised the Turks also for the way they treated street dogs. Istanbul's dogs were one of the topics mentioned by most foreign visitors to the Ottoman capital. As Hálek put it, Constantinople's dogs are so noticeable that "perhaps not a single traveler has omitted them from his notes." ${ }^{203}$ Like other phenomena, here again the Turks' attitudes toward dogs were interpreted in opposite ways: Klaus contrasted the miserable dogs in the European neighborhoods of Constantinople, where they were driven out of stores, with the fatter and healthier dogs in the "Turkish" neighborhoods, where they were treated well, 204 but other writers considered the street dogs another sign of the shambles that was Istanbul. ${ }^{205}$ Istanbul's dogs made such a powerful impression that Čech used them as the subject for a short story: a dog called Žoli, inspired by a German essay on freedom that he read, runs away from Prague and goes to Constantinople, and there he writes letters to his former master. In these letters,

\footnotetext{
199 Klaus, Do ř́še půlměsíce, 197-98.

200 Ibid., 223-25.

201 Ibid., 223-26.

202 Ibid., [279]. Also Klaus sometimes criticized the Turks, but he praised them more than other travelers did.

203 Hálek, Cestopisy, 163. See also Kaminský, Návštěvou u chorého muže, 71; Girinon, "Constantinople."

204 Klaus, Do říše půlměsíce, 192.

205 Kaminský, Návštěvou u chorého muže, 71. Štolba (Ze slunných koutů Evropy, 135-41) on the one hand remarked that street dogs could not wish for better "owners" than the Turks, who treated them in an almost fatherly manner, but on the other hand he dwelled on the dirt and smells that the dogs lived in. Guth (Letem pres řecký kraj, 141) wrote similarly about dogs in Izmir. Svátek (V zemi půlměsíce, 113-18) devoted over four pages to this topic and compared the characteristics of Istanbul's street dogs to the character of the Turks (114).
} 
the dogs of Istanbul have characteristics that resemble the stereotypes of the Turks: they are honest, proud, and straightforward, but also jealous, unrefined, and incredibly dirty. They do not recognize different social classes, which the observer at first appreciates but later finds excessive. Life is quiet, neither noise nor the expectation that they should work disturbs the dogs' sleep. In his first letters, Žoli enthusiastically describes the free life of Constantinople's dogs, but he eventually starts to miss his old life. Žoli's adventure ends when he encounters a European traveler who is about to write derogatory things about Constantinople's street dogs, and then is attacked by other dogs for trying to persuade the traveler that at least some dogs in Constantinople are educated. Hurt, Žoli returns home to his old master, and to the safety of his servitude. ${ }^{206}$

Istanbul's dogs figured frequently in European or - thinking of Mark Twain's famous diatribe about Constantinople's street dogs ${ }^{207}$ - world travelogues on the Ottoman Empire. Images of these dogs spread across countries and were passed on over the centuries, but they were interpreted and used in different ways - just like images of the Ottoman Empire and the men and women who lived in it were.

\section{5}

\section{Women}

If there was a topic that attracted the attention of Czech travelers even more than Istanbul's dogs, it was Ottoman women. Svátek was expressing a widely held opinion when he wrote that "the Turkish woman of whom we hear and read so much in Europe is certainly something particularly attractive to every foreigner in the land of the crescent."208 Initially, there seems little original about Czechs' views on the life of Ottoman women: they, like other European travelers, saw Turkish women as the embodiment of the Oriental, the exotic, and the different. Czech travelogues on the Ottoman Empire likewise represent a masculine view of Oriental eroticism and the masculine experience of this eroticism. But Czech writers did not equate the Ottoman Empire or the Orient with femininity and the West with masculinity, as British travelers commonly did. As Nash notes, especially "[r]omantic Orientalism, influenced by

\footnotetext{
206 Svatopluk Čech, "Žoli," in $V$ cizích zemích, dalekých krajích: Výbor z povídek českých spisovatelů 19. a počátku 20. století o exotice a dalekých cestách, ed. Lucie Kořínková (Prague: Knižní klub, 2014), 85-100. I would like to thank Olga Lomová for bringing the story to my attention.

207 Mark Twain, The Innocents Abroad, or the New Pilgrim's Progress (New York: Signet, 1980), $265-67$.

208 Svátek, Vzemi půlměsíce, 51.
} 
the Arabian Nights, represented the Turk as barbarous, cruel and effeminate."209 Leaving aside a few brief remarks on eunuchs, who are not associated ethnically with the Turks, Czech travelogues do not connect the Turks or "the Orientals" with effeminacy. Perhaps memory of the strength and violence of the Ottoman army, which was revived in connection with the fights of the $1870 \mathrm{~s}$, prevented Czechs from characterizing Ottoman men and their society as effeminate. $^{210}$

Two viewpoints mingled in the descriptions of Turkish women: a focus on the subordinate position and oppression of women, and an emphasis on the women's exotic appeal as objects of the imagination. ${ }^{211}$ These two outlooks came together in images of the harem, which could be described both as a prison and as a realm of (sexual) fantasies. ${ }^{212}$ Although many Czech men hinted at the sexual appeal of Turkish women, in their travelogues they devoted more attention to the conditions of women's lives. The image produced in these men's writings was quite similar: women lived in the harem completely segregated from the world, they depended on men, and their position was comparable to slavery; consequently, they were uneducated, as only rich families hired female governesses for their daughters; they could not choose their husbands, were considered men's property, and had to obey their spouses and spend their time in idleness or devoting excessive care to their appearance. The travelers who took an interest in women's and family life provided details on marriage as a contract, weddings, relations between husband and wife, and divorce, noting that the laws on inheritance were rather favorable to women and that Turkish women had extensive rights regarding their own property. ${ }^{213}$ Some observers remarked that polygamy was becoming increasingly rare because it was too expensive and difficult to deal with more than one wife. Occasionally eunuchs ${ }^{214}$ and slavery ${ }^{215}$ were mentioned in connection with a discussion of women's lives in the harem, but such notes are rare and incidental enough to suggest that these subjects were not of paramount interest to the Czechs.

209 Nash, "Politics, Aesthetics and Quest," 59; Vesna Goldsworthy, "The Balkans in NineteenthCentury British Travel Writing," in Youngs, Travel Writing in the Nineteenth Century, 30.

210 However, as we could see in the previous chapter, some hints at Turks as effeminate appeared in the late 1870 s and early 1880 s in Krásnohorská's poems.

211 Hálek, Cestopisy, 192-96; Svátek, Vzemi půlměsíce, 1 and 7.

212 Kaminský, Návštěvou u chorého muže, 94-95; Guth, Letem přes řecký kraj, 137; Svátek, Vzemi půlměsíce, 51-57 and 166; Klaus, Do řišse půlměsíce, 229; Raušar, Na půdě sopečné, 52 and 130.

213 Svátek, Vzemi půlměsíce, 53.

214 Klaus, Do řišse pưlměsíce, 232; Kaminský, Návštěvou u chorého muže, 101.

215 Klaus, Do říše půlměsíce, 232. 
Czech travelers sometimes used exactly the same images and examples, which they copied from each other or drew from the same sources; intertextuality was a common device in European travel writing more generally and in descriptions of travels to Istanbul specifically. ${ }^{216}$ Klaus and Svátek, for example, both argued that despite their general subjugation some Turkish women were able to attain a position in society that was almost equal to that of European women. ${ }^{217}$ But they also both pointed out that there was no family life among the Turks and no closeness between husband and wife in the way Europeans knew these things; women could not accompany their husbands out in public, and men and women did not eat together. ${ }^{218}$ Similar imagery notwithstanding, overall evaluations of the position of women varied: Klement, writing in the 189os, said that despite their deplorable status, akin to that of slaves, and their segregation and dependence on men, women in the Orient to him seemed happier than their half-free counterparts in Western Europe. ${ }^{219}$ Svátek offered inconsistent depictions of the position of Ottoman-Turkish women, suggesting that there were contradictions in their status (or perhaps differences among the sources on which he based his remarks), and Klaus argued that some women were now reluctant to sell their bodies into marriage: emancipated women began to appear in Turkey who had been educated in European culture and thought for themselves, and they understood very clearly the miserable position that Turkish women were in. 220

Travelers who regarded the position of women as deplorable tended to see this as a reflection of the conditions - whether backward or slowly improving that existed in the empire more generally. Descriptions of the treatment of women, with examples of how they are looked upon as hens and sheep, ${ }^{221}$

\section{Girinon, "Constantinople."}

217 Svátek, V zemi půlměsíce, 53; Klaus, Do řiše půlměsíce, 228. It is unclear whether both Svátek and Klaus used the same source or whether Klaus copied the information from Svátek, whose travelogue was published earlier. Svátek certainly devoted more attention to this topic (Vzemi pưlměsíce, 53-56). He wrote, for instance, that men stay in the harem from sunset to sunrise, the ease of divorce means that many men divorce repeatedly, even 20 times, some men are underfoot and women are stronger, especially if they come from more important families than their husbands. Klaus (Do řiše půlměsíce, 226-28) described the same phenomena and sometimes in exactly the same way.

218 Svátek, Vzemi pưlměsíce, 56; Klaus, Do ř́šse pưlměsíce, 228 and 235.

219 Klement, “O Turkyních," 2.

220 Klaus, Do ř́še pưlměsíce, 231.

221 Čech (Upominky z Východu, 190) wrote of women being led to a boat in a manner that reminded him of sheep-herding, and described them being kept in a small space covered by a piece of fabric, resembling a poultry mew. Hálek (Cestopisy, 338) claimed that women themselves complained that they were treated like animals. 
were only rarely used as proof of the Turks' heartlessness. The most notable instance of the use of this imagery is provided by Hálek, who traveled to Istanbul in the mid-186os and, as we saw above, strongly disliked the Turks; he twice told the same story (with different details, but in the same spirit) about how he met some "Turkish" women on a boat and learned from them about the life of women in the Ottoman Empire. Drawing a parallel between the Turkish oppression of women and that of the Slavs, he likened Ottoman Turks to a vampire "drinking the blood of our [i.e. Czechs'] brothers"222 - or sisters. The women on the boat spoke "a Slavic language" and were at one point identified as Serbian, but Hálek nevertheless called them "Turkish women" and claimed to have learned from them what the fate of almost "all Turkish women" was: they were poorly treated by their husbands, beaten, starved, and used as sexual objects; the women, in turn, hated their husbands and wished them dead. ${ }^{223}$

As for the descriptions of what Ottoman women were like, they were portrayed by Czech travelers in a way that in many respects resembles depictions of Ottoman women in British travelogues, such as allusions that were made to Turkish women's sensuality and indolence, the attention given to veiling, or references to women's morals and chastity. ${ }^{224}$ In her classic work on British female travelers to the Middle East, Billie Melman argues that a dramatic change occurred in these travelogues in the 19th century - "the desexualisation of the Augustan notion of liberty and the domestication of the Orient."225 According to Melman, female travelers, increasingly from the middle class, projected onto the harem a bourgeois gender ideology with its concept of domesticity, femininity, and autonomy. Czech men (and women, for that matter, although they do not figure among our travelers) generally did not share the Victorian concepts of gender relations and differed from their British counterparts in their views on the role of women in society. Rather than "Victorian notions on the civilizing influence of women on the individual and society,"226 which British travelers felt applied also to the Ottoman Empire, Czech men expected Czech women to contribute to the nation and its progress. They did not, for the most part, transfer these views to the Ottoman Empire or compare Turkish and Czech women, but their belief that the position of women was an indicator of how advanced a society was could explain why they were more

\footnotetext{
222 Hálek, Cestopisy, 332-33.

223 Ibid., 332-40. For a shorter version of the same story see Hálek, Cestopisy, 192-96.

224 It is important to note, though, that the views of British travelers also varied and developed over time. On the difference between the 18th and the 19th centuries see Melman, Women's Orients, 59-162.

225 Ibid., 99.

226 Schiffer, Oriental Panorama, 284-85.
} 
concerned with the status of Ottoman-Turkish women than with other aspects of their lives. ${ }^{227}$

On the whole, male travelers were less interested in the character of women than in their position, though occasional comments that women were lazy, had loose morals, and lacked education do appear in various travelogues. While these characteristics could be seen as women's faults, they were more often interpreted as a reflection of the generally poor level of education in the Ottoman Empire. Some images that were common throughout Europe were introduced in Czech writing by references to the early modern travelogue of Mitrovic. Knotek pointed out that the only form of entertainment open to women who lived secluded lives and grew bored was to have a love affair, for which they used to be punished severely. He quoted Mitrovic's description of how adulterous women used to be sewn into a bag with a cat and thrown into the sea. ${ }^{228} \mathrm{He}$ went on, however, to say that Sultan Abdülmecid had put an end to these practices ${ }^{22}$ and allowed the harem women to meet European women, learn foreign languages, and attend theater performances, though they had to remain hidden during the performance. "He was a Turk half-changed by European civilization," and, Knotek concluded, he gave women some freedom and dignity. 230

Melman notes that even such themes as clothing, eating habits, and hygiene had a symbolic function (for instance, dress was used as a symbol of women's status in society) and were increasingly associated with feminine sexuality. ${ }^{231}$ In Czech men's travel writing these themes, perhaps with the excepton of veiling, appear only marginally. Most men found Turkish women's faces and their clothes exotic, though Klaus likened Turkish women's dresses to those of "our nuns,"232 and Hálek claimed that Turkish women and their harems were not much different from the monasteries of the Barnabites. ${ }^{233}$ Most travelers agreed that Turkish or Muslim and Oriental women more generally were beautiful, at least when they were young, like "princesses from a fairy tale,"234 with

227 On these views see Jitka Malečková, Úrodná půda: Žena ve službách národa (Prague: Isv, 2002), esp. 86-109.

228 Knotek, Balkán, 37-38.

229 When he learned that one of his wives was cheating on him, instead of killing her, he allegedly divorced her and forced her lover to marry her, which was believed to be the best punishment for them both. Knotek, Balkán, 38-40.

$230 \quad$ Ibid., 38.

231 Melman, Women's Orients, 102.

232 Klaus, Do ř́íše půlměsíce, 229.

233 Hálek, Cestopisy, 332.

234 Štolba, Ze slunných koutů Evropy, 121; see also Schwarzenberg, Pod praporem tureckého půlměsíce, 22. Schwarzenberg also mentioned that many Turkish women were educated and were fluent in French and some also spoke German. 
gorgeous ivory faces beneath their veils, soft lips, and bright eyes full of longing; ${ }^{235}$ travelers also noted that they devoted a lot of time to their appearance. ${ }^{236}$ The more modern or coquettish women wore only very light veils, which allowed the traveler to admire their exotic beauty, as Jiř́k and other European travelers before him observed; and he reckoned that the old and ugly ones perhaps wore thicker veils, because he did not recall seeing any ugly women. ${ }^{237}$ Others claimed that an idle life gradually affected women's appearance so that the older ones were fat and unattractive. ${ }^{238}$ Some travelers after 1908 mentioned having seen women without veils on promenades near villas and in parks. ${ }^{239}$

The place of sex in the travelogues varies. While more indirect allusions to the unknown pleasures hidden behind the veil and the harem walls are present in most, if not all, travelogues, direct references to prostitution or sexual experiences are less common. Several travelers mentioned being approached by prostitutes or their pimps when they were walking through the streets, but they had different views on the ethnic and religious identity of the prostitutes. Guth claimed that Muslim women used to come to some parts of Izmir to earn their dowry through prostitution, and that they were not ashamed of this; while, by contrast, women in the Greek and Armenian neighborhoods would be seated modestly alongside their husbands in front of their houses, a picture of family harmony. ${ }^{240}$ Another writer boasted having spent nights in Istanbul with three Greek sisters who took turns in his bed night after night. ${ }^{241} \mathrm{Few}$ travelers hinted at unusual sexual experiences or made comments to suggest that pederasty and sodomy were common in the Orient; Jiřík claimed, alongside other unusual sexual adventures, to have observed a woman having sex with a donkey in Alexandria, ${ }^{242}$ but such remarks are extremely rare.

Even Svátek, whose whole travel book is imbued with the spirit of and explicit references to the exotic Orient and the tales of The Thousand and One

235 Svátek, Vzemi půlměsíce, 49.

236 Klaus, Do ř́šse pưlměsíce, 23; Svátek, V zemi pưlměsíce, 57. According to Hálek (Cestopisy, 201), Turkish women used too much make-up.

237 Jiř́k, K pyramidám, 34. Jiřík's comment referred specifically to Alexandria in 1913. Svátek (Vzemi pülměsíce, $5^{6}$ ) also mentioned that young and coquettish women wore light veils.

238 Klement, “O Turkyních," 2.

239 Klaus, Do říše půlměsíce, 229-30. Schwarzenberg (Pod praporem tureckého půlmèsíce, 85) saw women without veils in Beirut during the war; he thought that one of them was Halide Edib.

240 Guth, Letem přes řecký kraj, 149-50. Also Klement ("O Turkyních," 2) described the morals of Turkish women as loose.

241 Moravec, Cesta do Orientu, 118-20.

242 Jiř́k, K pyramidám, 50-67. 
Nights, and who devoted more attention to Turkish women than most, if not all, of the other Czech travelers, does not describe them in sexual terms. Svátek's Turkish women are attractive, but they are depicted as interesting paintings, rather than living women or objects of the author's lust. Svátek does not seem to take possession of the women he writes about and the story of how he watched a group of about 200 Turkish women near the railway station in Bursa is quite telling. He recounts that he was so fascinated by their number, their sincere cheerfulness, and the beauty and coquetry of some of them that he could not stop watching them, and as a result - and as symbolic punishment for his voyeurism - he missed his train. ${ }^{243}$ The whole scene, though it includes references to the women's beautiful skin and to them gazing lustfully at him, is mostly humorous in tone and does not portray the author as a male hero and conqueror. If Western male travelers take possession of the Orient by exerting control over its women, as Said and many after him have suggested, ${ }^{244}$ Czech men, by generally avoiding scenes in which they describe or imagine themselves sexually possessing Ottoman women, in this sense showed a lack of aspiration to control the Ottoman Orient.

Czech authors' use of the tropes and views about women that were common in European travel books points to the popularity of Western Orientalist literature in the Czech milieu. Svatek suggested this himself when he wrote about the Turkish women "of whom we hear and read so much in Europe."245 This similarity with European travel literature, however, should not overshadow the deeper difference between the use and framing of gendered images of the Ottoman Empire and Turkish women: Czech writings seem in most cases to be free from this desire to "possess" the Orient that is observed in the Western works they were often modeled on.

\section{The Turks and Others}

Like similar writing produced elsewhere in Europe, Czech works on Turkish themes written in the late 19 th and early 20 th centuries contained references to figures that were more important Others for the Czechs - namely the Jews and

\footnotetext{
243 Svátek, Vzemi půlměsíce, 226-29.

244 Ulrike Stamm, "Oriental Sexuality and Its Uses in Nineteenth-Century Travelogues," in Hodkinson et al., Deploying Orientalism, 230; on older examples of such attitudes see Harrigan, Veiled Encounters, esp. 171.

245 Svátek, Vzemi půlměsíce, 51.
} 
the Roma - and they sometimes mixed ethnic and racial stereotypes. ${ }^{246}$ In an early 19th-century drama by Josef Linda, Jaroslav Šternberg v boji proti Tatarům (Jaroslav Šternberg in Combat against the Tatars), the Tatars are associated with "bloodthirstiness, ferocity, and cruelty," but the main villain and traitor, an alleged "Tatar," turns out to be a Roma. ${ }^{247}$ Czech visitors to the Ottoman Empire showed little interest in the Roma, except for some passing remarks that were usually made by travelers in the Ottoman Balkans, and their views on the Roma were generally negative. According to Knotek, the Gypsies in Macedonia, described as short with white teeth and black hair, were the true embodiment of every negative saying about Gypsies: to steal like a Gypsy, to beg like a Gypsy, to lie like a Gypsy, and to swear like a Gypsy. ${ }^{248}$ In the same vein, the Middle Eastern scholar Jan Rypka wrote in a footnote to his translation of Muallim Naci's autobiographic novel Ömer'in Çocukluğu (Omar's Childhood): “[i]n Turkey, Gypsies do not enjoy a better reputation than in our country. Neither Christianity, nor Islam has changed them. They are engaged everywhere in the same honorable and dishonorable crafts that immediately come to our mind when we hear the word 'Gypsy."'249

The Jews, who were important Others for late 19th- and early 2oth-century Czechs, occupied a more prominent place in travelogues than the Roma. Ottoman Jews sometimes received brief mention in the parts of a text in which they were not the main subject, but they were usually described in detail in the parts of the travelogue devoted to the empire's heterogeneous population. The Jews are presented either alongside the Greeks and Armenians as merchants and moneylenders ${ }^{250}$ or in relation to their idiosyncratic way of life and habits. In the late 189os, Guth wrote that in Izmir, Jews lived in poor conditions in their

246 Jonathan Boyarin, "The Other Within and the Other Without," in The Other in Jewish Thought and History: Constructions of Jewish Culture and Identity, ed. Laurence Jay Silberstein and Robert L. Cohn (New York: New York University Press, 1994), 424. Hálek connected "Gypsy, Armenian [and] Moor women and beggars" in the very title of one his travel sketches (Cestopisy, 200-203), where only the beggars appear in a gender-neutral form; he considered Arab and Moor women inatractive compared to the beautiful Armenian women.

247 Josef Linda, Jaroslav Šternberg v boji proti Tatarům (Prague: Nákladem České akademie věd a umění, 1930), 163, 16, and 29. In her collection of poems devoted to the Balkans and the Slavs, Krásnohorská ( $K$ Slovanskému jihu, 156) mentions briefly, but perhaps more symptomatically for its matter-of-factness, a sly Gypsy woman with a shallow soul - a harlot, empty, and without country or faith.

248 Knotek, Balkán, 67-69.

249 See Rypka's notes in Mu'allim Nádží-Effendi, Omarovo dětství: Až do jeho osmého roku, transl. (with introduction and comments by) Jan Rypka (Prague: J. Otto, 1913), 116 (footnote 117$)$.

250 Knotek, Balkán, 7; Kořenský, Asie, 206; Svátek, Vzemi pưlměsíce, 101. 
own filthy neighborhood, where their dirty progeny toddled through litter, while fat formless women chirped in a Spanish dialect and the men tried to cheat foreigners. Instead of Mustafas, Ismails, and Mohammeds, he went on, the çarşı (market) was full of Isaacs, Abrahams, and Salomons, but since antiSemitism was in fashion, they pretended to be Turks. He alleged that the local Greeks envied the Jews and spread stories about them: as well as accusing them of blood libel, they would say, for instance, that wherever a Jew sowed his seeds the land went to waste, and when a Jew wanted to paddle the boat would not move. ${ }^{251}$ According to Knotek, the Jews in Macedonia resembled the local population in every respect, but clung stubbornly to their own religious habits. "Every respect" was probably just a hyperbolic flourish, as Knotek then described the Jews as short, with red hair and yellow eyes, as smart but superstitious, as abhorring hard work, but happy to trade in anything and lend money. Knotek claimed that a Jew, even if rich, would walk around in dirty and ragged clothes with garlic in the pocket of his caftan, pretending to be poor. Recycling an accusation against the Jews common in the Czech lands, he wrote that, like everywhere else, they were able to persuade the local population that they sell things at a cheaper price than others, while in fact they found ways to cheat the people. ${ }^{252}$ Other travelers paid less attention to the Jews in the Ottoman Empire, but they revealed how widespread anti-Semitic prejudices were simply by means of their casual comments about the Jewsas heartless ${ }^{253}$ moneylenders, ${ }^{254}$ or as a sign of God's trial (of the traveler). ${ }^{255}$

When it comes to casting aspersions on other ethnic or religious groups, the Jews were but one of a number of targets of Czechs' criticism. The Czechs expressed similarly unsympathetic views about Greeks and Armenians. It was not uncommon for other Europeans to compare and lump these three groups together, too: in the early 2oth century, Germans called the Armenians and the Greeks the "Jews of the Orient" and branded them exploiters, usurers, and

251 Guth, Letem přes řecký kraj, 152-54.

252 Knotek, Balkán, 70-74.

253 Hálek, Cestopisy, esp. 38-39.

254 Nĕmec, Má cesta do Afriky, 70-71.

255 Raušar (Na půdě sopečné, 124-25) described a young Jew in a European style of dress, who looked, however, completely Eastern, and he wrote about "a Jewish invasion" of a train he was riding on. Jiř́k (K pyramidám, 20) in the same vein remarked that for one good deed done by a Jew on a boat he had forgiven the Jews the crucifixion of Jesus. Numerous negative Jewish figures appear in Hořica's writing about the Balkan struggles and the resulting impression of the Turks is certainly more positive than that of the Jews. See Ignát Hořica, Smutné i veselé z Bosny a Hercegoviny (Prague: J. Otto, 1909), esp. 13-16. 
politically disloyal inhabitants of the Ottoman Empire. ${ }^{256}$ Czechs often mentioned these three ethnic groups in one breath and depicted them as exceptionally skilled and sly merchants, cheating and growing rich through moneylending. ${ }^{257}$ Their character, according to travelers, could be summed up with the saying: "A Jew can trick three Christians, a Greek three Jews, but the Armenian three Greeks." 258

The Greeks in particular were associated with trade and considered liars, cheats, and boasters. ${ }^{259}$ Knotek claimed that they were deceitful and were ready to use any means to control the Slavic population, and thus ingratiated themselves with the Turks, who rewarded them with special treatment. ${ }^{260}$ Even the propagator of Greek Olympic ideas, Jiří Guth, who came to visit and admire ancient Greek monuments, was ambivalent in his views about contemporary Greeks. He wrote that owing to their agility and quick-wittedness the Greeks in Izmir were able to drive the Turks out of many professions; they fraternized with the Turks and even accepted posts in the government. They formed the intelligentsia of Izmir and were more open to European mores and innovations. Nevertheless, Guth considered even those Greeks who had moved to Izmir from their homes in Paris or London and who spoke perfect French or English unable to rid themselves of their "Oriental customs," claiming they had bad manners and left a mess everywhere. ${ }^{261}$ The Armenians fared little better: although Kořenský, writing after the war, considered them hard-working, ${ }^{262}$ earlier travelers had described them as domineering and sly, incapable of hiding their Asian origin, and hated by others due to their financial skills. ${ }^{263}$ Čech

256 Eric D. Weitz, "Germany and the Ottoman Borderlands: The Entwining of Imperial Aspirations, Revolution, and Ethnic Violence," in Shatterzone of Empires: Coexistence and Violence in the German, Habsburg, Russian, and Ottoman Borderlands, ed. Omer Bartov and Eric D. Weitz (Bloomington: Indiana University Press, 2013), 162.

257 Štolba, Ze slunných koutů Evropy, 103; Svátek, V zemi půlměsíce, 101; Knotek, Balkán, 42; Kořenský, Asie, 206. Wagner (Na evropském východě, 195) mentions that the Greeks, Armenians, and Bulgarians have an inborn trade spirit.

258 Kořenský, Asie, 206; Knotek, Balkán, 8.

259 Svátek, Vzemi půlměsíce, 101; J.V. Daneš, Balkán po válce roku 1913: S mapkou poloostrova S dnešním politickým rozdělením (Prague:J.R. Vilímek, n.d., ca. 1914), 40. See also Nĕmec, Má cesta do Afriky, 22-23.

26o Knotek, Balkán, 8, 42, and 6o.

261 Guth, Letem pres řecký kraj, 127 and ${ }^{150-52}$. It is perhaps worth noting that Guth was known as the arbiter of etiquette.

262 Kořenský, Asie, 206.

263 Knotek, Balkán, 62; Svátek, Vzemi půlměsíce, 101; Kořenský, Asie, 206. 
summed up his opinion on the Armenians of Istanbul by saying that they resembled spiders waiting to catch a fly. ${ }^{264}$

As well as the Jews, Armenians, and Greeks, who also interested travelers from other European countries, ${ }^{265}$ Czechs devoted attention to the Slavs and other ethnic groups who were living under Ottoman rule. The Slavs were depicted in a more positive light than the Jews or the Greeks, but not as faultless, and travelers were less unanimous in their opinions on various Slavic groups than they were on the Greeks, who were clearly disliked, in part because of their perceived mistreatment of the Slavs. Knotek described the Bulgarians in Macedonia as hard-working, forthright, cordial, and hospitable (a Bulgarian is "not like a Greek or an Armenian"266), but Daneš judged the Bulgarians to be debased, in contrast to the moral strength of the Serbs. ${ }^{267}$ Pomaks, the "Turkified Bulgarians," were believed to get preferential treatment from the Turks and Knotek considered them to be even worse than the Turks themselves. ${ }^{268}$ In contrast, he depicted the Tatars as good farmers, honest, and patient, but prone to "breed like rabbits" because they practised polygamy. ${ }^{269}$ Svátek claimed that the Circassians and Kurds had disreputable morals and that the Levantines combined the good and bad qualities of the East and the West and were flirtatious, sly, and cunning. ${ }^{270}$

It is thus clear that the Turks were far from the only object of negative stereotyping. In fact, when travelers compared the Turks with other ethnic groups of the Ottoman Empire, the comparison was not necessarily to the detriment of the Turks. For instance, Daneš considered the Turks comparable to the Greeks and Albanians in terms of their ability to boast and in terms of their moral strength. ${ }^{271}$ Štolba appreciated the Turks and the Persians as unobtrusive and honest merchants and explicitly contrasted them with the glib and dishonest Greeks, Armenians, and Jews. ${ }^{272}$ The Turks were often seen as exotic and were sometimes mocked, but they were generally not described as

264 Čech (Upominky z Východu, 187) spent all his money in Istanbul and held the Armenians responsible for this.

265 On British travelers' views of the Greeks, Armenians, and Jews see Schiffer, Oriental Panorama, 265-73; on German views see Weitz, "Germany and the Ottoman Borderlands," 162. See also Božidar Jezernik, Wild Europe: The Balkans in the Gaze of Western Travellers (London: Saqi Books, 2004), esp. 209.

266 Knotek, Balkán, $5^{2}$.

267 Daneš, Balkán po válce roku 19ı3, 33.

268 Knotek, Balkán, 7 and 58.

269 Ibid., 63 and 66-67.

270 Svátek, Vzemi půlměsíce, 101-2.

271 Daneš, Balkán po válce roku 19ı3, 40.

272 Štolba, Ze slunných koutů Evropy, 103. 
qualitatively different from other ethnic groups of the Ottoman Empire with whom they shared, first and foremost, an "Oriental" or "Asian" character.

\section{$7 \quad$ Conclusion}

If the pamphlets of the late 1870 s depicted "the Turk" primarily as a violent and cruel warrior and an enemy of Christians and above all the Slavs, Czech travel writing does not create any uniform image of the Turks. The general impressions drawn from visiting the empire varied and views on the Turks also ranged from strongly negative (Hálek), to ambivalent (Neruda) and to prevailingly positive (Klaus). A single author could even express wildly varying opinions about the Turks. The inconsistencies in the depictions of the Turks are occasionally the result of the authors' inability to resist using a fitting or clever image created by somebody else, even when it contradicted their overall opinion on the Ottoman Empire. Their personal encounters with Ottoman reality only rarely inspired travelers to question and alter the preconceptions with which they had set out on their travel. Sometimes, however, they did change their mind, adding nuances to their views of the Turks, for instance, when they made a distinction between the educated intellectual elites they met, and the general masses of the population who fit the stereotype of uneducated Turks.

Czech travel writing on the Ottoman Empire was in dialogue with past and present works on the Turks, both Czech and foreign. This made Czech travel accounts rather eclectic, a characteristic they shared with travel literature on the Middle East at the time. ${ }^{273}$ They reproduced stereotypes and prejudices that can be found in older Czech travelogues and contemporary pamphlets for example, images of the Turks as lazy, fatalist, violent, and cruel (more seldom also fanatic) and prone to bribery. The overall image that this travel literature produced, however, differed from the image generated by the antiTurkish pamphlets in the 1870s; it was more heterogeneous and less onesidedly negative; it was more nuanced and less unequivocal. Travelers seemed less persuaded of the negative impact of Islam, which they mostly described with interest and sometimes respect rather than hatred, and they wrote less about the Turks as the Slavs' oppressors.

Czechs also "picked up" ideas and images from Western works. The various types of attitudes toward the Orient that had evolved gradually and had long been articulated in Western Europe found their way into the works of Czech

273 Deborah Manley, "Introduction," in Knowledge Is Light: Travellers in the Near East, ed. Katherine Salahi (Oxford: ASTENE and Oxbow Books, 2011), viII. 
writers in the late 19th century. Some Czech authors shared the dismissive attitudes toward Ottoman attempts at modernization already expressed by Western travelers, while others praised such efforts; some wrote nostalgically about the loss of traditions, while others considered their continued existence to be a sign of backwardness. Czech accounts of journeys to the Ottoman Empire resembled West European travel literature in their tendency to both exoticize and domesticate what they had seen, in the way they described the panoramic views of the Bosphorus and the streets of Istanbul, including its street dogs, and in their evocation of a general Oriental setting on the one hand, and specific Orientalist images on the other. Svátek, the cosmopolitan writer whose words introduced this chapter, is a striking example of such an impact and of the Orientalist rhetoric and imagery borrowed from Western works. ${ }^{274}$

But Czech travelers did not simply reproduce Western literature. Unlike West European travelers, who often showed little interest in the contemporary inhabitants of the Middle East, ${ }^{275}$ Czech visitors to the turn-of-the-century Ottoman Empire paid attention not only, and often not particularly, to historical sites, as they also took an interest in the people around them. They evidently had limited contact with the ordinary Turkish-speaking population and they mostly interacted with foreigners or minorities who spoke European languages, but they still commented on contemporary intellectuals, imams, and others whom they observed or met. Furthermore, in contrast to their Western counterparts, Czech travelers paid no or little attention to Oriental despotism or to racial issues and racial mixing. Even their depictions of Ottoman women, including the Orientalist images in Svátek's travel book, were focused less on women's morals and sexuality than on their position in the family and society. This is linked to a deeper difference between Czech and Western travelers - a lack of Czech colonial interests in the Ottoman Empire. For the Czechs, who had no independent nation-state of their own, colonial expansion to the Ottoman Empire was not a real prospect, nor even a dream that they harbored. Before the war their attention was focused on more local problems and aims that lay within the Habsburg Empire and if they dreamed about a colonial enterprise at all, they did not locate it in the Ottoman realm. They did not have to justify any historical intervention in Ottoman affairs by criticizing despotic Ottoman rule, and they did not care about racial mixing in the Ottoman Empire, which did not concern Czech society. ${ }^{276}$

\footnotetext{
274 This "Orientalization" distinguished Czech travel writing from that of Southeast Europeans who, as Bracewell noted, did not find Ottoman reality exotic but rather familiar.

275 Gregory, "Scripting Egypt," 145; see also Nash, "Politics, Aesthetics and Quest," 56.

276 Racial mixing bothered some nationalists when it concerned the Jews in Czech society, but this was not reflected in travel literature on the Ottoman Empire.
} 
It can be discerned in the writing of Czech travelers that there was not so much at stake for the Czech nation in the Ottoman Empire and Czech travel and travel writing were often motivated by simple curiosity, rather than by any political interests. What was "political" for the Czechs was the question of Ottoman rule over the Balkan Slavs, which occasionally influenced their thoughts about the fate of the Ottoman Empire and its expulsion from Europe. But despite their lack of expansionist plans Czech travelers clearly felt superior to the local population. Their sense of superiority stemmed from their identification with Europe. The travelogues helped to reaffirm this sense of superiority over the Ottoman Turks, a feeling that derived from the perceived preeminence of Europe, to which the Czechs unanimously felt they belonged, over the "Orient," the realm to which they assigned not just the Turks but also other inhabitants of the Ottoman Empire. Czechs' opinions on the Turks thus should not be viewed in isolation; the accounts of their travel to the Ottoman Empire reveal the prejudices and various negative views they held of other ethnic groups in the Ottoman Empire as well.

While their works resembled other East European travelogues in terms of the importance they placed on being European, the Czechs did not use the Ottoman Empire as a mirror against which to establish their society's place in Europe, and instead seem to have taken their Europeanness for granted, at least in relation to the Ottoman Empire. They did not extol the virtues of Christianity over Islam and felt no need to show how different they were from the Ottoman Turks, though they did stress the difference between the Ottoman Empire and Europe. They traveled primarily as Europeans. The travelers' Czechness was most visible when they compared what they observed on their journey with similar phenomena at home and when they focused on their compatriots in the Ottoman Empire. They did not represent the Habsburg Empire: those who called for the withdrawal of the Ottoman Empire from the Balkan territories were mostly speaking in the name of the Slavic brotherhood, and not from the perspective of the Habsburg Empire. The Czechs' allegiance to the Habsburg Empire and to its mission and interests does not figure in their travel writing on the Ottoman Empire. This does not mean, as we will see in the next chapter, that Czechs could not identify with Austria-Hungary or have colonial ambitions of their own. 